\title{
Organic Amendment Effects on Soil Carbon and Microbial Biomass in the Root Zone of Three Landscape Tree Species
}

\author{
P. Eric Wiseman, Susan D. Day, and J. Roger Harris
}

\begin{abstract}
There is increasing interest in amending degraded soils with organic matter to improve soil quality, especially in urban areas where rehabilitation of damaged soils may enhance tree growth and provision of ecosystem services. To assess the potential of such organic amendments for producing a sustained alteration in soil biological characteristics, researchers studied the effects of three organic amendments incorporated into the root zone of three tree species on root development, soil carbon dynamics, and soil microbial biomass over one year beginning 20 months after amendment application. Soil amendment with leaf-based, and to a lesser extent, biosolids-based composts increased root length within the amended root zone of red maple (Acer rubrum), but not of pin oak (Quercus palustris) or chestnut oak (Q. montana). There was a concomitant increase in microbial biomass carbon for red maple. Across all species, sphagnum peat moss amendment reduced microbial biomass carbon by $47 \%$ compared to unamended root zones and suppressed maximum seasonal soil respiration relative to composts. In contrast, leaf-based compost increased microbial biomass carbon by $12 \%(P=0.0989)$ compared to unamended root zones. Carbon/nitrogen ratios remained stable throughout most of the year except in the root zones of chestnut oak and pin oak amended with peat, where it declined $44 \%-85 \%$. Total soil carbon was stable in all treatments, although unamended soils averaged about $40 \%$ lower than amended soils. Across all species and treatments, cumulative fine root length explained $19 \%$ of the variation in microbial biomass carbon. The study authors conclude that soil microbial activity can be increased by compost amendment of the root zone and that this increase is mediated to some degree by tree roots. In addition, stable $\mathrm{C} / \mathrm{N}$ ratios suggest this alteration in the root zone may be sustainable. Further research may clarify whether compost amendment combined with tree planting can accelerate soil restoration.

Key Words. Acer rubrum; Quercus montana; Quercus palustris; Soil Food Web; Soil Rehabilitation; Soil Respiration; Tree Roots; Urban Soil.
\end{abstract}

Land-use changes and management practices have long-term effects on soil ecology and consequently on the provision of ecosystem services. Urbanization in particular results in highly altered soils, which has profound repercussions for urban ecosystems. Urban soils typically have disrupted or absent horizons, are compacted, have poor structure, and possess low organic matter (Jim 1998; Pouyat et al. 2007). These soils may also have diminished microbial populations, particularly on recently disturbed sites (Scharenbroch et al. 2005). Soil microorganisms are integral to the soil food web because of their role in the decomposition of organic matter (Wardle 1999; Scheu 2002). As such, they are critical drivers of nutrient cycling, nitrogen fixation, nitrification, and the aggregation of clay particles (Lynch and Bragg 1985; Lee and Pankhurst 1992; Tejada et al. 2009). In addition, soil microbial communities can exert significant control on soil carbon dynamics (Grandy et al. 2009) and thus on the global carbon cycle (Doran 2002).

Organic amendments, particularly compost, are receiving renewed attention in the context of restoring disturbed urban soils to address environmental issues as well as improve tree growth. For example, improved vegetative growth and water infiltration resulting from soil rehabilitation can improve water quality by mitigating stormwater (Cogger 2005). Organic amendments (e.g. peat and compost) in urbanized landscapes are generally targeted at improving soil physical properties in the short term to aid in transplant establishment (e.g., Day et al. 1995). Less familiar benefits ascribed to organic amendments include suppression of root pests (Hoitink et al. 1997; Widmer et al. 1998; Forge et al. 2008) and elicitation of enzymatic or hormonal growth responses by plant roots (Chen et al. 1994; Raviv 1998). However, few studies have examined whether organic amendments can affect soil health through their influence on the soil microbial community. Cheng and Grewal (2009) found that amending subsoil with compost prior to lawn establishment enriched the nematode food web (i.e., content of macronutrients, organic matter, and microbial biomass), but had little effect on nematode food web structure (i.e., abundance and diversity of nematode genera).

Disturbance and subsequent management of urban soil is quite different from the more frequently studied agricultural and forested systems. In urban settings, drastic soil alterations during land development may be followed by relatively stable management regimes-especially where trees are planted-potentially creating opportunities to restore functional soil microbial communities that can promote nutrient cycling and plant health. Although trees play a prominent role in urban ecosystem function (Nowak and Crane 2002; McPherson et al. 2005; Nowak 2006; McDonald et al. 2007), no studies, to the knowledge of the authors, have investigated the effects of organic matter amendment on the soil microbial community in the context of landscape tree planting.

Microbial biomass has been reported to be most often limited by the availability of soil carbon rather than nitrogen (Ekblad and Nordgren 2002), although the role of nitrogen may be influenced 
by soil C/N ratio in certain circumstances (Månsson et al. 2009). Besides the deliberate incorporation of organic matter, carbon enters soil from plant litter, carbon-rich rhizodeposition products (e.g., root exudates, dead cells, $\mathrm{CO}_{2}$ ), and dead roots (along with their associated mycorrhizae) (Grayston et al. 1997). As much as $40 \%$ of carbon assimilated through photosynthesis is returned to the environment through rhizodeposition (Lynch and Whipps 1990; van Veen et al. 1991), and nearly half of carbon allocated to fine roots and mycorrhizae can be deposited into soils as roots turn over (Fogel and Hunt 1983). Not only does soil carbon increase activity of microorganisms, but the presence of microorganisms can induce positive feedback responses that increase root exudation, further enhancing soil carbon content (Meharg and Killham 1991). Root carbon therefore exerts a significant influence on the soil microbial community (Brant et al. 2006).

The purpose of this study was to examine the effects of organic matter amendment on soil carbon dynamics and microbial activity within the root zone of trees planted into soil unoccupied by plants and to determine if these effects could be sustained over time. The soil surrounding the roots of newly transplanted trees was amended with organic matter and researchers measured the effects on soil carbon dynamics, microbial biomass, and tree growth up to 33 months after treatment. Researchers studied three deciduous tree species of contrasting cultural requirements, transplanted with three distinct types of organic matter incorporated into the backfill soil of their planting holes. The research objectives were to determine 1) if a single application of organic matter could alter carbon dynamics and increase soil microbial activity within the root zone; 2) whether the type of organic matter and tree species would influence these outcomes; and 3 ) whether these changes might be attributable to enhanced root production and rhizodeposition in the amended backfill soil.

\section{MATERIALS AND METHODS}

\section{Study Site and Experimental Design}

The study was conducted at the Virginia Tech Urban Horticulture Center in Blacksburg, Virginia, U.S. (USDA Hardiness Zone 6b) from March 2004 to December 2006. Soil at the center is a Groseclose silt loam (fine, mixed, semiactive, mesic Typic Hapludults); typical bulk density and $\mathrm{pH}$ of the Ap horizon (0-18 $\mathrm{cm}$ ) is $1.05-1.35 \mathrm{~g} \mathrm{~cm}^{-3}$ and 6.1-6.7, respectively (Harris et al. 2008). Average annual precipitation is about $109 \mathrm{~cm}$, and the growing season typically lasts from early May to mid-October.

The experiment consisted of three tree species and four backfill soil treatments combined factorially and replicated four times each in a completely randomized design, totaling 48 experimental units. The backfill soil treatments were unamended site soil $(\mathrm{CON})$, and site soil amended with sphagnum peat moss (PM), leaf-based compost (LBC), or biosolids-based compost (BBC) as described in Table 1. See Bowden et al. (2007) for additional information concerning the preparation of LBC and BBC.

In March 2004, bare-root, seedling-grown pin oak (Quercus palustris Münchh.), red maple (Acer rubrum L.), and chestnut oak (Quercus montana Willd.) were randomly assigned to a backfill soil treatment and a planting location within five adjacent planting rows measuring $35 \mathrm{~m}$ long $\times 2 \mathrm{~m}$ wide $(3.5 \mathrm{~m}$

Table 1. Soil amendments incorporated into backfill soil during transplanting of bare root, hardwood tree seedlings to a field site in Blacksburg, Virginia, U.S., in March 2004.

\begin{tabular}{|c|c|c|c|c|c|c|c|c|c|c|}
\hline Amendment & Description $^{z}$ & $\mathrm{pH}$ & $\begin{array}{l}\mathrm{TKN}^{\mathrm{y}} \\
(\mathrm{g} / \mathrm{kg})\end{array}$ & $\begin{array}{l}\mathrm{PAN}^{\mathrm{x}} \\
(\mathrm{mg} / \mathrm{kg})\end{array}$ & $\begin{array}{l}\text { Total Pw } \\
(\mathrm{g} / \mathrm{kg})\end{array}$ & $\mathrm{C}: \mathrm{N}$ ratio & $\begin{array}{l}\text { TOC } \\
(\mathrm{g} / \mathrm{kg})\end{array}$ & $\begin{array}{l}\text { Gravimetric } \\
\text { moisture } \\
\text { content }(\%)\end{array}$ & Manufacturer & $\begin{array}{l}\text { Amendment } \\
\text { method }\end{array}$ \\
\hline Control & $\begin{array}{l}\text { Unamended } \\
\text { native silt loam }\end{array}$ & $6.1-6.7$ & $\mathrm{n} / \mathrm{a}$ & $\mathrm{n} / \mathrm{a}$ & $\mathrm{n} / \mathrm{a}$ & $\mathrm{n} / \mathrm{a}$ & $\mathrm{n} / \mathrm{a}$ & $\mathrm{n} / \mathrm{a}$ & $\mathrm{n} / \mathrm{a}$ & Soil only \\
\hline Peat moss & $\begin{array}{l}\text { Pro-Moss 'Emerald' } \\
\text { Canadian sphagnum } \\
\text { peat moss }\end{array}$ & 4.8 & $\mathrm{n} / \mathrm{a}$ & $\mathrm{n} / \mathrm{a}$ & $\mathrm{n} / \mathrm{a}$ & 125 & $\mathrm{n} / \mathrm{a}$ & $\mathrm{n} / \mathrm{a}$ & $\begin{array}{l}\text { Premier Horticulture, } \\
\text { Quakertown, } \\
\text { Pennsylvania, U.S. }\end{array}$ & $\begin{array}{l}\text { Hand-mixed 1:4 } \\
\text { volumetric } \\
\text { ratio peat } \\
\text { moss to native } \\
\text { soil }\end{array}$ \\
\hline $\begin{array}{l}\text { Leaf-based } \\
\text { compost }\end{array}$ & $\begin{array}{l}\text { Finely ground yard } \\
\text { waste composted } \\
\text { with poultry litter } \\
\text { at } 1: 2 \text { volumetric } \\
\text { ratio for four months }\end{array}$ & 6.6 & 17 & 2,623 & 4.1 & 18 & 311 & 159 & $\begin{array}{l}\text { Panorama Pay-Dirt, } \\
\text { Earlysville, Virginia, } \\
\text { U.S. }\end{array}$ & $\begin{array}{l}\text { Hand-mixed 1:4 } \\
\text { volumetric } \\
\text { ratio compost } \\
\text { to native } \\
\text { soil }\end{array}$ \\
\hline
\end{tabular}

${ }^{\mathrm{z}}$ See Bowden et al. (2007) for more details on properties and production process of these composts.

y Total Kjeldahl Nitrogen EPA 351.3 (USEPA 1979)

${ }^{x}$ Plant available nitrogen estimated by adding $100 \%$ of the measured $\mathrm{N}$ and the fraction of organic $\mathrm{N}$ estimated to be mineralizable during the first seasons. Mineralization coefficient of 0.1 .

w Total phosphorus EPA method SW846-6010B (USEPA 1996) 
spacing between trees). Planting rows had been uniformly prepared by killing the turfgrass with glyphosate (Roundup®, Monsanto Co., St. Louis, Missouri, U.S.) and tilling the topsoil to $15 \mathrm{~cm}$ depth at the end of the previous growing season. Average height of red maple, chestnut oak, and pin oak trees at planting were $2.9 \mathrm{~m}, 3.5 \mathrm{~m}$, and $3.6 \mathrm{~m}$, respectively.

Trees were placed in holes dug $45 \mathrm{~cm}$ deep with a $61 \mathrm{~cm}$ diameter mechanized auger, backfilled to grade with the assigned soil treatment, and thoroughly irrigated. Trees were then secured to a wire trellis spanning each planting row and mulched with a $5 \mathrm{~cm}$ deep $\times 2 \mathrm{~m}$ wide layer of uniform, shredded hardwood bark that was replenished seasonally for the duration of the study. The pre-emergent herbicide pendimethalin (Pendulum ${ }^{\circledR}$ Aquacap, BASF Corp., Florham Park, New Jersey, U.S.) was applied to planting rows every March, and weeds were spot-treated during the growing season with the post-emergent herbicide glyphosate. Trees were drip-irrigated once per week during the first growing season and then only during protracted drought in subsequent growing seasons.

\section{Sampling and Measurements}

In November 2005 (20 months after planting), researchers began a yearlong series of monthly soil and root measurements. Six measurement sub-plots were established equidistant around the perimeter of the amended root zone of each tree about $22 \mathrm{~cm}$ from its trunk. Each sub-plot was used for measurements during two consecutive months and then abandoned. Two weeks prior to each monthly measurement session, a PVC ring (10.1 $\mathrm{cm}$ inside diameter $\times 16 \mathrm{~cm}$ height) was placed at the center of the selected sub-plot and pressed through the mulch and into the soil to a $3 \mathrm{~cm}$ depth. Subsequently, soil respiration and temperature were concurrently measured using a LI-6400-09 Soil $\mathrm{CO}_{2}$ Flux Chamber coupled with a LI-6400 Portable Photosynthesis System (LI-COR Biosciences, Lincoln, Nebraska, U.S.). The flux chamber was affixed to the PVC ring, and the thermocouple was inserted $6 \mathrm{~cm}$ into the soil adjacent to the PVC ring. Volumetric soil moisture content was simultaneously measured adjacent to the PVC ring with a 6-cm dielectric probe $\left(\mathrm{TH}_{2} 0\right.$ Soil Moisture Meter, Dynamax, Houston, Texas, U.S.). Equipment malfunction prevented measurements during April 2006; therefore, the experiment was extended through November 2006 to achieve twelve monthly sampling sessions.

Immediately following the second monthly sampling of respiration, temperature, and moisture at a measurement sub-plot, a $5 \mathrm{~cm}$ diameter soil core was extracted from the sub-plot center at $0-10 \mathrm{~cm}$ soil depth. Soil samples were first passed through a $6 \mathrm{~mm}$ sieve to collect coarse mineral fragments, coarse woody debris, and coarse tree roots. The coarsely-sieved soil was then passed through a $2 \mathrm{~mm}$ sieve to prepare soil sub-samples for carbon-nitrogen analysis. In addition, thin tree roots $(2-6 \mathrm{~mm}$ diameter) were manually collected from the sieve and fine tree roots ( $<2 \mathrm{~mm}$ diameter) were manually collected from the sieved soil using methods described by Oliveira et al. (2000). Root fractions were then compiled for each core sample, washed, digitized using a flatbed computer scanner, and analyzed for physical dimensions using WinRHIZO Pro software (Regent Instruments, Quebec, Canada). Roots, mineral fragments, and woody debris were then oven dried at $65^{\circ} \mathrm{C}$ and weighed. Sub-samples of the finely-sieved soil were also oven dried at $65^{\circ} \mathrm{C}$ and then analyzed for total carbon and nitrogen content by dry combustion with an automated gas combustion analyzer (Vario MAX CNS elemental analyzer, Elementar Instrument, Mt. Laurel, New Jersey, U.S.).

In October 2006, soil samples were collected from the amended root zone of each tree to assay microbial biomass carbon (MBC). Three sub-samples per tree were collected with a $2.5 \mathrm{~cm}$ diameter corer at 0-7 cm soil depth and homogenized. All samples were immediately covered with a wet paper towel and quickly passed through a $2 \mathrm{~mm}$ sieve. Two, $25 \mathrm{~g}$ sub-samples were then collected from each sieved sample and each kept in a constant field-moist condition by placing in a sealed desiccator chamber along with $250 \mathrm{ml}$ of distilled water for 24 hours. One of each pair of samples was then processed for MBC assay according to the chloroform fumigation extraction method of Horwath and Paul (1994). Fumigation destroys membranes and cell walls, allowing subsequent extraction of cell constituents with $0.5 \mathrm{M} \mathrm{K}_{2} \mathrm{SO}_{4}$. The extraction procedure was performed on both fumigated and non-fumigated samples and extracted constituents were shipped frozen to the Soil Analytical Service Laboratory at North Carolina State University (Raleigh, North Carolina, U.S.) for total organic carbon (TOC) analysis using a TOC-5050 analyzer fitted with an ASI-5000 autosampler (Shimadzu Corporation, Kyoto, Japan). Total MBC of the extractant was calculated as the difference between TOC in fumigated and non-fumigated samples using an extraction efficiency factor of 0.35 (Voroney et al. 1991). Soil MBC was then calculated by adjusting extractant volume for soil mass and correcting for gravimetric moisture content at the time of sampling.

\section{Statistical Analysis}

Measured values of response variables were first screened for normality and homogeneity of variance; violations of these assumptions were corrected through natural log transformation of the measured values prior to statistical analysis. Response variables were analyzed using repeated measures ANOVA with the PROC MIXED procedure of SAS ver. 9.1 (SAS Institute, Cary, North Carolina, U.S.). Where main effects of independent variables were significant, multiple comparisons of response means were conducted using the LSMEANS PDIFF option. Where there were significant interactions between independent variables, the LSMEANS SLICE and DIFF options were used to test their simple effects on response variables. Microbial biomass carbon was analyzed using a twofactor ANOVA with the PROC GLM procedure. Multiple comparisons of treatment factor levels were performed using Tukey's HSD test. Regression models were created in JMP ver. 9.0.2 (SAS Institute, Cary, North Carolina, U.S.).

\section{RESULTS}

\section{Root Growth}

There was a marginally significant tree species $\times$ soil amendment interaction $(P<0.075)$ for both total and fine root length (Table 2). There was a significant species difference in root mass, but no interaction with soil amendment measured during the second year after treatment. Red maple had greater root mass than both chestnut oak and pin oak. Although the relationship varied among amendment $\times$ species for root length, both total and fine root length were always lower in 
chestnut oak than in pin oak and red maple (Figure 1; only fine roots depicted). On average, fine root length accounted for $91 \%-96 \%$ of total root length across species during the year.

Soil amendment had no effect on root mass, total root length, or fine root length during the 12-month sampling period (Table 2). However, there was a marginally significant tree species $\times$ soil amendment interaction for both root length metrics. Further analysis of the interaction revealed that soil amendment was significant for red maple $(P<0.05)$, but not for chestnut oak or pin oak (Figure 1). Averaged across sampling dates, both total and fine root length of red maple were greatest in LBC and lowest in PM and CON (Figure 1; only fine roots depicted). Red maple root length in $\mathrm{BBC}$ was intermediate, but not statistically different from the other treatments.

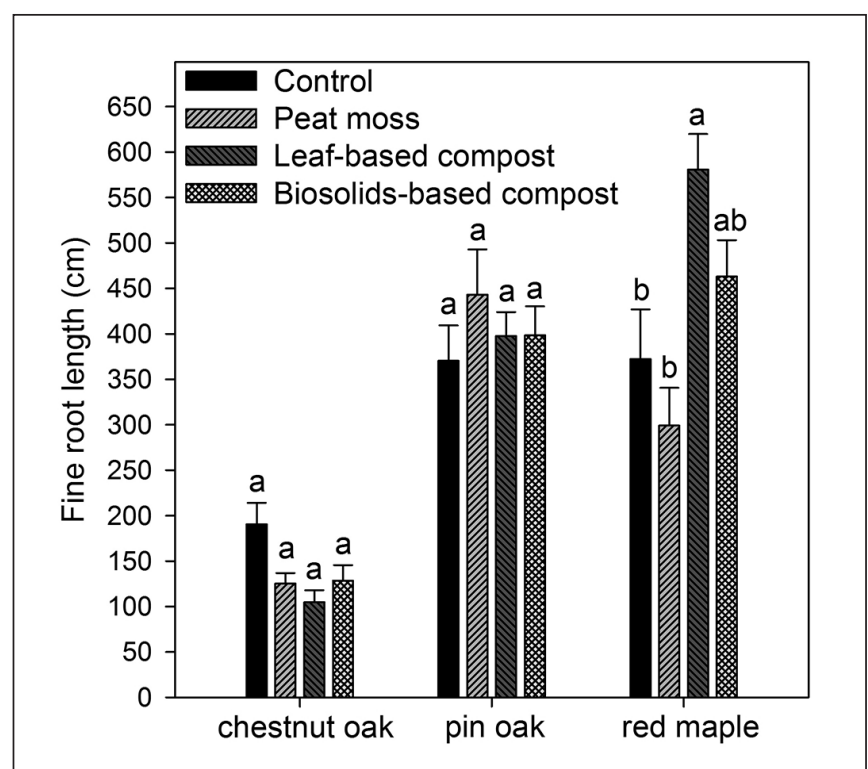

Figure 1. Fine root length ( $<1 \mathrm{~mm}$ diameter) of bare root tree seedlings 33 months after transplant into field soil amended with three organic amendments. Roots were sampled with a $5 \mathrm{~cm}$ diameter soil core at the $\mathbf{0 - 1 0} \mathrm{cm}$ soil depth in the backfill region. Each value is pooled across six bi-monthly measurement dates $(n=24)$ and error bars depict standard error of mean. Within each species, letters denote significant effects due to soil treatment $(\alpha=0.05)$.

\section{Soil Carbon-Nitrogen Dynamics}

Although no species-related differences were observed in soil carbon content, nitrogen content, or $\mathrm{C} / \mathrm{N}$ ratio during the second year after treatment, soil amendment significantly affected $(P<0.01)$ all three metrics (Table 2$)$. Because there was a significant tree species $\times$ measurement date interaction, amendment effects on soil carbon, nitrogen, and $\mathrm{C} / \mathrm{N}$ ratio were analyzed within species. Soil carbon was stable through time (no significant date effect) and averaged about $40 \%$ lower in CON than in the three amended soils, which did not differ from one another (Figure 2). In contrast, nitrogen content was more dynamic through time for all tree species (all date main effects, $P<0.05$ ), generally showing modest increases during the sampling year (Figure 3). Within species, there was no interaction be-

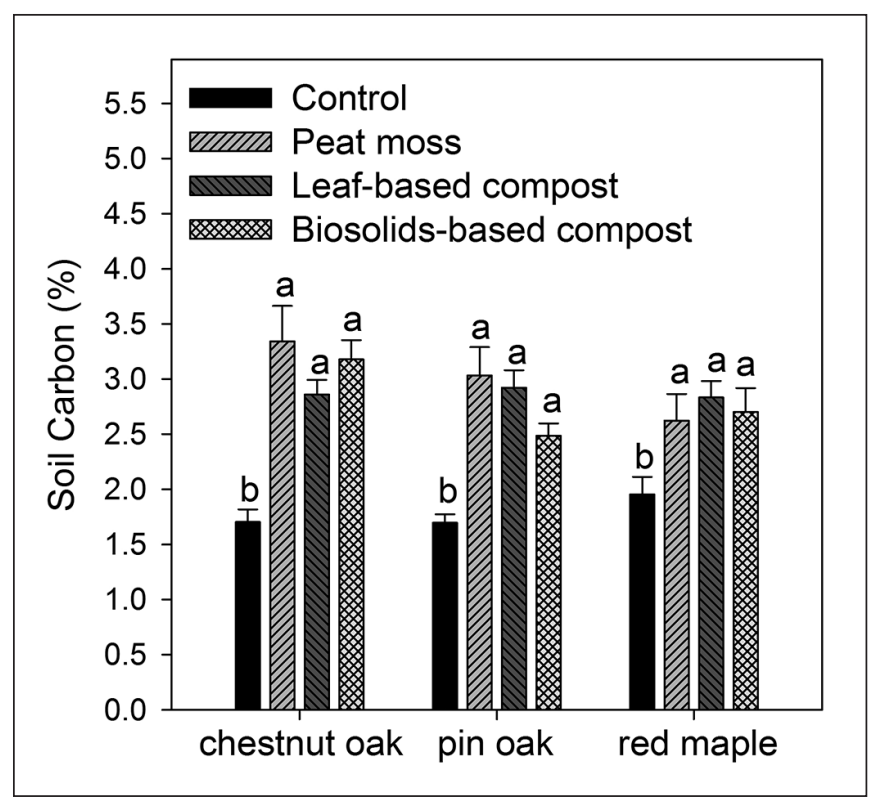

Figure 2. Soil carbon content at $0-10 \mathrm{~cm}$ soil depth in root zones of bare root tree seedlings 33 months after transplant into field soil amended with three organic amendments. Each value is pooled across six bi-monthly measurement dates $(n=24)$ and error bars depict standard error of mean. Within each species, letters denote significant effects due to soil treatment $(\alpha=0.05)$.

Table 2. Significance level of main effects and interactions of tree species (TS), soil amendment (SA), and measurement date (D) for response variables measured during the second year after tree transplant and soil treatment.

\begin{tabular}{|c|c|c|c|c|c|c|c|}
\hline & \multicolumn{3}{|c|}{ Main effects } & \multicolumn{4}{|c|}{ Interactions } \\
\hline & $\mathrm{TS}$ & SA & $\mathrm{D}$ & $\mathrm{TS} \times \mathrm{SA}$ & $\mathrm{TS} \times \mathrm{D}$ & $\mathrm{SA} \times \mathrm{D}$ & $\mathrm{TS} \times \mathrm{SA} \times \mathrm{D}$ \\
\hline & \multicolumn{3}{|c|}{$\mathrm{P}<\mathrm{F}^{\mathrm{z}}$} & \multicolumn{4}{|c|}{$\mathrm{P}<\mathrm{F}^{2}$} \\
\hline Root dry mass & $* * *$ & NS & NS & NS & NS & NS & NS \\
\hline Total root length & $* * *$ & NS & $* *$ & $*$ & NS & NS & NS \\
\hline Fine root length & $* * *$ & NS & $* * *$ & $*$ & NS & NS & NS \\
\hline Soil carbon content & NS & $* * *$ & NS & NS & $* *$ & NS & NS \\
\hline Soil nitrogen content & NS & $* * *$ & $* * *$ & NS & $* *$ & $* *$ & NS \\
\hline Soil $\mathrm{CO}_{2}$ efflux rate & NS & $* *$ & $* * *$ & NS & $* * *$ & $* *$ & NS \\
\hline Soil moisture (v/v) & $* * *$ & $* *$ & $* * *$ & NS & $* * *$ & NS & NS \\
\hline
\end{tabular}

${ }^{\mathrm{z}}$ Analysis of variance using PROC MIXED; NS denotes not significant at $\alpha=0.075$; Asterisks $(*),(* *)$, and $(* * *)$ denote significance at $\alpha=0.075, \alpha=0.05$, and $\alpha=$ 0.01 , respectively. 
tween soil amendment and measurement date. Although the response varied across species, nitrogen content was generally higher in $\mathrm{BBC}$ and $\mathrm{LBC}$ than in $\mathrm{CON}$ and $\mathrm{PM}$, which never significantly differed in all cases (Figure 3).

Both two-way and three-way interactions were found between the independent variables for soil $\mathrm{C} / \mathrm{N}$ ratio (Table 2). Further analyses by species revealed a significant soil treatment $\times$ measurement date interaction for pin oak, but not for chestnut oak or red maple (hence the three-way

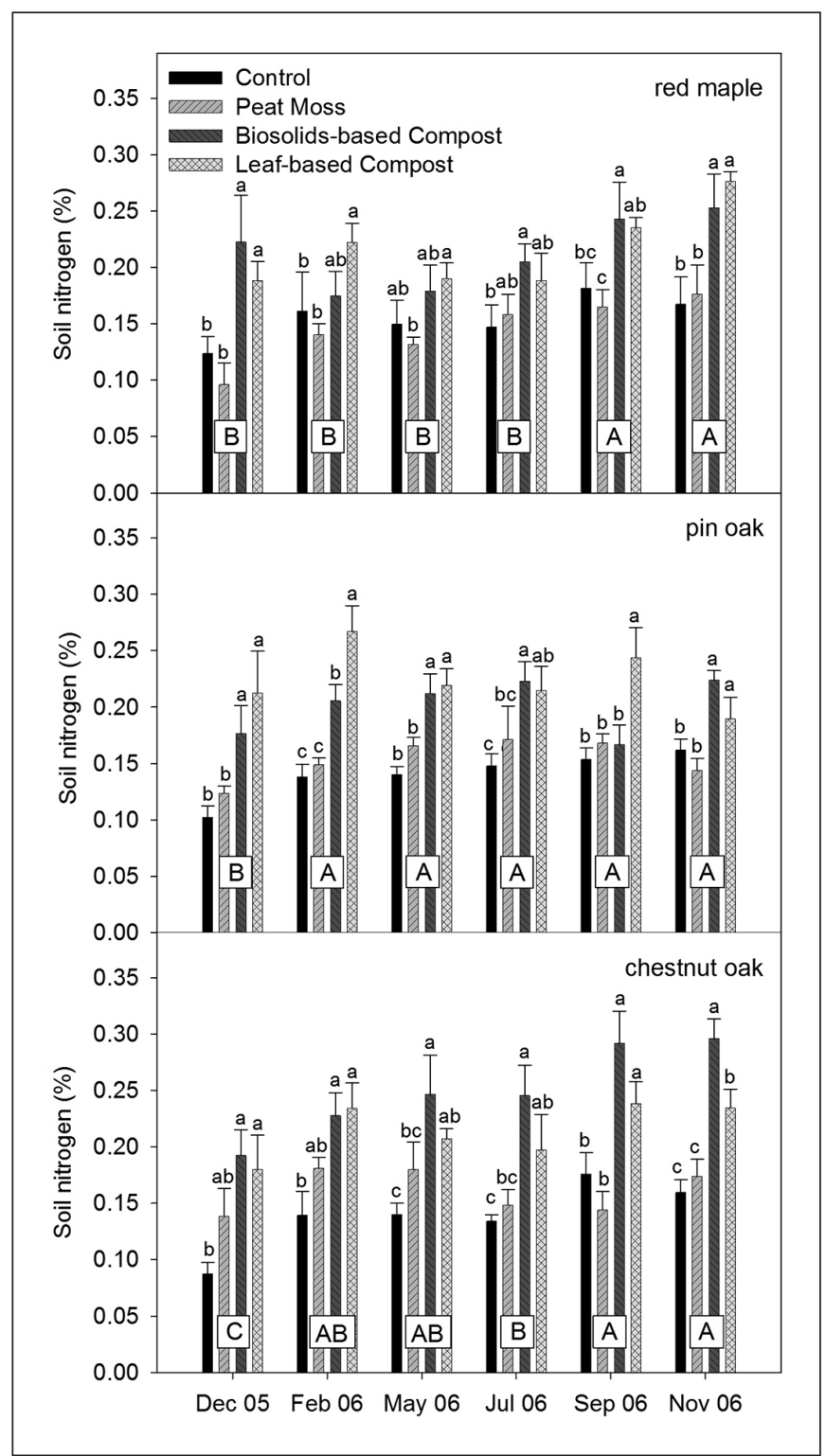

Figure 3 . Soil nitrogen content at $0-10 \mathrm{~cm}$ soil depth in root zones of bare root tree seedlings $\mathbf{3 3}$ months after transplant into field soil amended with three organic amendments. Within each date, lowercase letters denote significant differences in soil treatments $(n=4)$. Within each species, uppercase letters denote significant differences in measurement dates $(n=16)$. For all analyses, $\alpha=0.05$. interaction in the three-factor model, see Table 2). Within species, soil $\mathrm{C} / \mathrm{N}$ ratio was dynamic through time (all date main effects, $P<0.05$ ). In red maple and chestnut oak, $\mathrm{C} / \mathrm{N}$ ratio was greatest on the first date irrespective of soil treatment (Figure 4). In contrast, a date effect was only present with the PM treatment for pin oak; here, $\mathrm{C} / \mathrm{N}$ ratio showed a more progressive decline through the year (Figure 4). Averaged across species and dates, $\mathrm{C} / \mathrm{N}$ ratio of $\mathrm{PM}$-amended soil was about $52 \%$ higher than the other treatments.

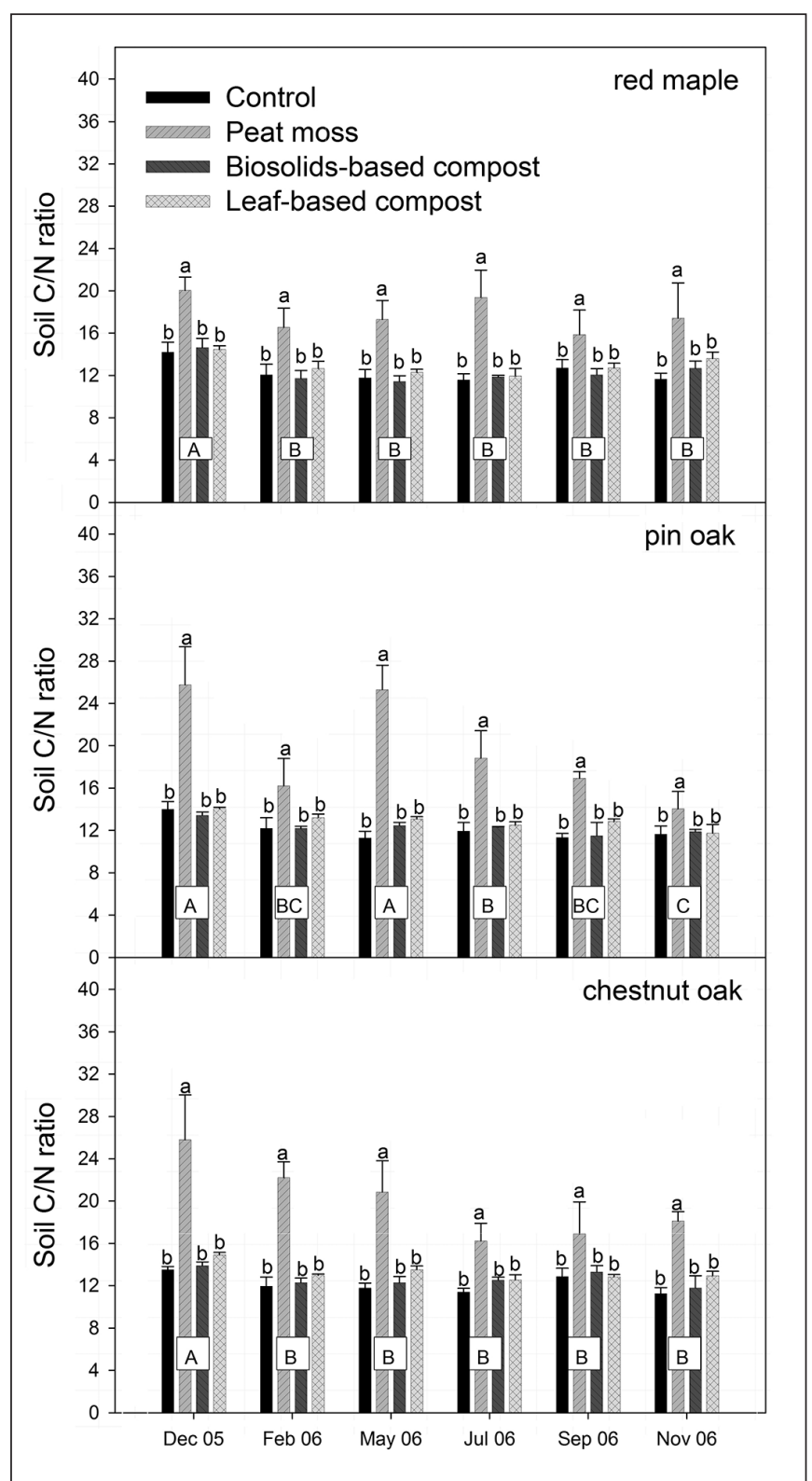

Figure 4. Soil $\mathrm{C} / \mathrm{N}$ ratio at $0-10 \mathrm{~cm}$ soil depth in root zones of bare root tree seedlings $\mathbf{3 3}$ months after transplant into field soil amended with three organic amendments. Within each date, lowercase letters denote significant differences in soil treatments $(n=4)$. Within each species, uppercase letters denote significant differences in measurement dates $(n=16)$. For pin oak, the date effect was only significant for peat moss and therefore uppercase letters apply to date differences for peat moss treatments only. For all analyses, $\alpha=0.05$. 


\section{Soil Microbial Biomass Carbon}

Soil MBC was measured at the end of the third growing season after transplant differed across tree species as well as soil treatments; there was no interaction between the two independent variables (Table 3). On average, MBC of PM-amended soil was $47 \%$ less than CON $(P<0.0001$; Table 3$)$. In contrast, LBC increased MBC of backfill soil by $12 \%$ compared to $\mathrm{CON}(P=$ $0.0989)$ and $65 \%$ compared to PM $(P=0.001)$; although MBC was higher in $\mathrm{BBC}$ backfill soil than in $\mathrm{CON}$, there was little or no evidence this was due to treatment $(P=0.2444)$. Averaged across backfill treatments, MBC was significantly lower in chestnut oak than in red maple and pin oak, which did not differ from one another. Regression analyses revealed significant $(P<0.001)$ but weak relationships between MBC and cumulative fine root length, $\mathrm{C} / \mathrm{N}$ ratio, and soil nitrogen (Figure 5). A multivariate model for $\mathrm{MBC}$ with these parameters explained $61 \%$ of the variance in MBC across all species and treatments:

$$
\mathrm{MBC}=77.4+0.00589 \mathrm{l}_{\mathrm{f}}+162.7 \mathrm{n}-3.04 \mathrm{c}
$$

where $1_{\mathrm{f}}=$ cumulative fine root length, $\mathrm{n}=\%$ soil $\mathrm{N}$, and $\mathrm{c}=$ $\mathrm{C} / \mathrm{N}$ ratio. $\mathrm{MBC}$ was unresponsive to $\mathrm{C} / \mathrm{N}$ ratio when $\mathrm{C} / \mathrm{N}$ ratio was below 14. However, since only peat moss addition resulted in higher $\mathrm{C} / \mathrm{N}$ ratios in this study, it cannot be determined if the resulting lower $\mathrm{MBC}$ was due to higher $\mathrm{C} / \mathrm{N}$ ratios or some other characteristic of peat moss. Likewise, percent soil $\mathrm{N}$ was relatively consistent within a given treatment, and thus its influence on MBC cannot be easily separated from treatment effects.

\section{Soil Respiration}

Although soil $\mathrm{CO}_{2}$ efflux rate (respiration) did not differ across tree species, differences were observed among soil backfill treatments as well as sampling dates. Because there were significant tree species $\times$ measurement date, and soil amendment $\times$ measurement date interactions, amendment effects on soil respiration were analyzed within species. For all species, soil respiration was lowest during the winter months (minimum in February) and highest during the summer months (maximum in July) (Figure 6). However, soil treat- ment did not significantly affect soil respiration of chestnut oak. In red maple and pin oak, soil respiration differed among treatments on three dates and two dates, respectively. Although the compostamended soils had a tendency to have higher soil respiration than CON or PM-amended soil, the effect was not consistent. The effect was most pronounced for red maple in July 2006. Neither soil temperature nor soil moisture was a significant covariate of respiration in the presence of other effects in the MIXED model (data not shown).

\section{DISCUSSION}

\section{Organic Amendment Effects}

Did the single application of organic matter alter carbon dynamics and result in increased soil microbial activity within the root zone?

Organic amendments sustained enhanced carbon content in amended root zones for up to 33 months after treatment (Figure 2). Researchers also found good evidence that compost amendment enhanced microbial activity, with leaf-based compost increasing MBC compared to the control $(P=0.0989$; Table 3$)$ across all species and a strong spike in summer soil respiration occurred in both compostbased treatments for red maple (Figure 6). The relative contributions of increased root length (in red maple) and increased microbial biomass to enhanced soil respiration were not quantified. However, past research has shown that roots contribute about $45 \%$ of total soil respiration annually in a forested environment (Hanson et al. 2000).

Other studies have found increased microbial activity after compost amendment. However, the amended soils studied were in arid or semi-arid environments with an inherently low microbial activity and were of relatively short duration ( $<90$ days) (Roldan et al. 1994; Pascual et al. 1997). In addition, many studies have used uncomposted materials or immature compost, where decomposition of the material may result in temporary increases in microbial activity. Annabi et al. (2007) found immature compost produced a short-term spike in microbial activity in the first two months after application, whereas mature compost did not increase microbial

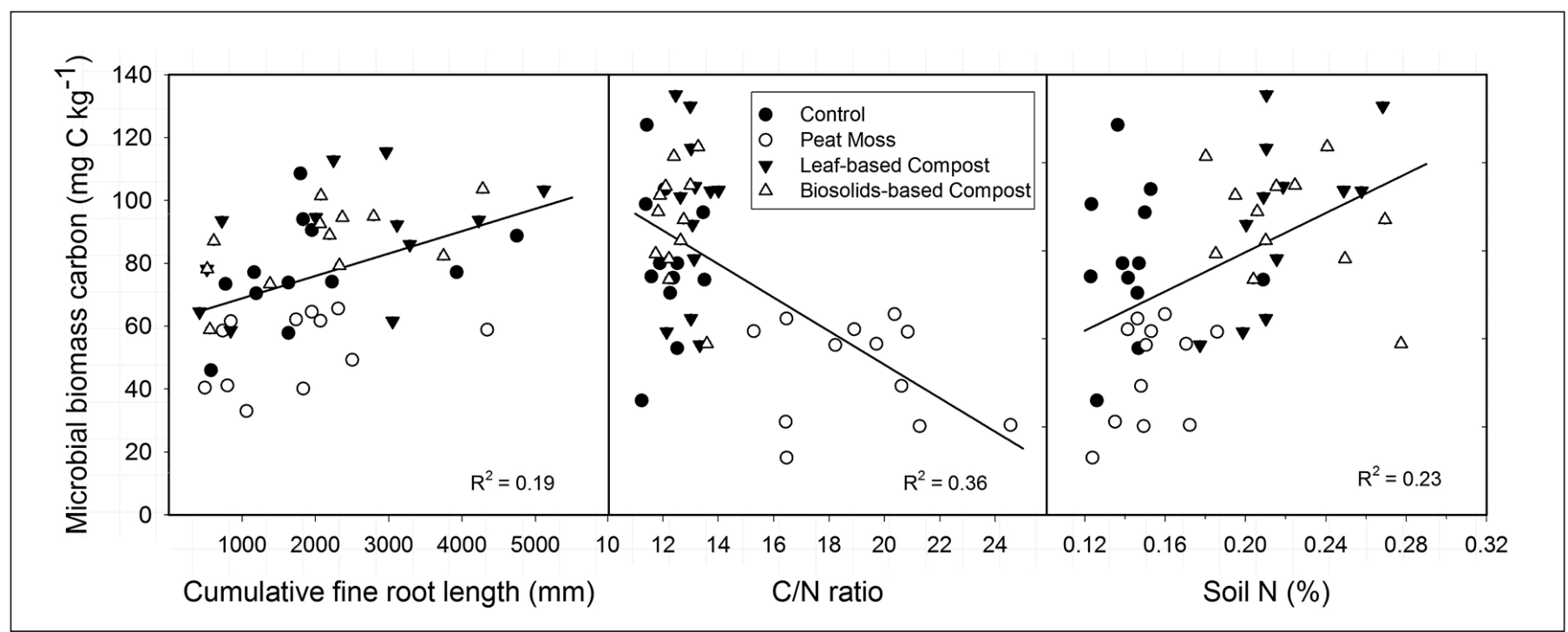

Figure 5. Relationship of fine root length, $\mathrm{C} / \mathrm{N}$ ratio, and Soil $\mathrm{N}$ to microbial biomass carbon at $0-10 \mathrm{~cm}$ soil depth in root zones of bare root tree seedlings 33 months after transplant into field soil or field soil amended with one of three organic amendments. 


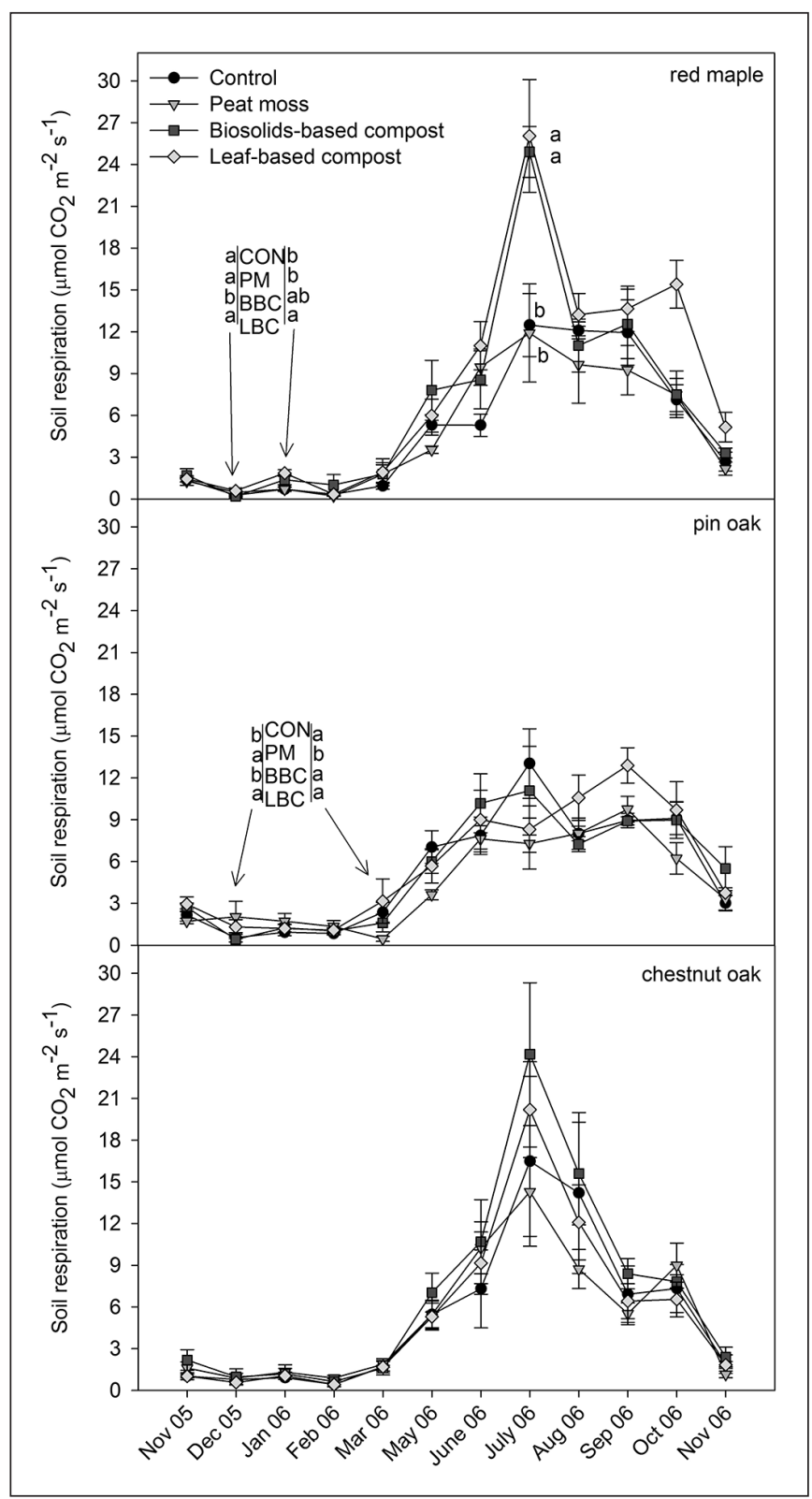

Figure 6. Soil respiration measured in the root zone of bare root tree seedlings 33 months after transplant into field soil amended with three organic amendments. Error bars depict standard error of mean $(n=4)$. Letters indicate significant effects due to soil amendment $(\alpha=0.05)$.

activity until approximately two months had passed. Cheng and Grewal (2009) found that both subsoil and topsoil amended with compost and seeded to turfgrass experienced a rapid increase in microbial biomass, but this enhancement declined markedly in the subsequent year. In contrast, it was found that mature compost marginally enhanced microbial biomass carbon as long as 33 months after application in a temperate zone soil with somewhat low initial organic matter content (Table 3). Although microbial biomass was only assessed late in the study, consistent soil carbon content and soil respiration patterns during the measurement period suggest that enhancement of microbial activity had been achieved. Because a source of ongoing carbon input (i.e., tree roots) was present, soil carbon may not have been as limited in the soil at the study site as it might be in soil on newly developed urban land with sparse vegetation (Scharenbroch et al. 2005).

\section{Did the type of organic matter and tree species influence these outcomes?}

Soil $\mathrm{C} / \mathrm{N}$ ratio was unaffected except for root zones amended with peat moss, where ratios were consistently higher than for unamended and compost-amended soils (Figure 4). Original $\mathrm{C} / \mathrm{N}$ ratio of the peat moss was very high (125) compared to leaf-based compost (18) and biosolids-based compost (17). In addition, $\mathrm{pH}$ of the peat moss was very low (4.8) and perhaps inhibitory to decomposing microbes. In this study, peat moss significantly suppressed microbial biomass carbon (Table 3) and soil respiration (Figure 6). Past work has investigated peat moss amendment to improve soil physical properties to enhance growth of trees (e.g., Day et al. 1995) and row crops (e.g., Pietola and Tanni 2003). The stability of peat moss perhaps contributes to its popularity as a soil amendment since its effect on soil physical properties can be long lasting. However, increased microbial activity has a positive effect on the building of soil structure (Lynch and Bragg 1985) as well as on aggregate resilience (Annabi et al. 2007), offering the potential for a longer term positive effect on soil quality.

In this study, incorporating peat moss decreased microbial biomass carbon (Table 3). These data are supported by the decreased soil respiration recorded during warm summer months for peatamended versus compost-amended backfill soil (Figure 6). Peatbased growing media are known for their limited microbial communities and thus their ability to suppress certain media-borne plant diseases although there is variation among peats from different sources (Chen et al. 1988). In contrast, there are very few studies examining the influence of peat on microbial biomass in mineral soils. Niklasch and Joergensen (2001) found that peat moss, in contrast to composts, did not increase microbial biomass $\mathrm{C}$ when incorporated into a silt loam soil. More recently in a study of strawberry cropping systems, Vestberg et al. (2009) found that microbial biomass $\mathrm{C}$ and $\mathrm{N}$ were lower in peat-amended field soil than in unamended soil. These results combined with the work presented here indicate that sphagnum peat moss may suppress soil biological activity; whether this is a direct effect or the result of limiting microbial resources is unknown. Notably, although red maple fine root length was lower in PM-amended soils than in soils with compost-based amendments (Figure 1), this was not the case for other species while MBC in peat-amended root zones was lower regardless of species (Table 3 ). This suggests that reductions in microbial activity did not likely inhibit fine-root growth per se. In addition, although sphagnum peat moss has historically been a common horticultural soil amendment and container media, peat harvest is largely considered a non-sustainable practice (Chapman et al. 2003), and is considered unacceptable for sustainable site development by some certification organizations (e.g., Sustainable Sites Initiative 2009), whereas composting utilizes what might otherwise be waste products. Amending soil with compost rather than peat may therefore be considered desirable for both sustainability and soil improvement practices.

Organic amendments clearly differed in their influence on microbial activity. Overall, the two composts had similar effects on MBC and soil respiration, while PM suppressed both MBC and soil respiration (Table 3; Figure 6). There were no significant effects of amendment on root growth for the two oak species. However, the effect on root length of red maple (Figure 1) followed the same pattern as the effects on $\mathrm{MBC}$, suggesting $\mathrm{MBC}$ 
Table 3. Microbial biomass measured in the root zone of bare root tree seedlings 33 months after transplant into field soil amended with three organic amendments. For each species $\times$ amendment combination, $n=8$ (standard error in parentheses). Within a column, lowercase letters denote significant differences $(P<0.05)$ in amendments. Pooled values are marginal means (and standard error) for treatment factors. Uppercase letters denote significant differences in marginal means.

\begin{tabular}{llll}
\hline & \multicolumn{2}{l}{ Soil microbial biomass carbon $\left(\mathrm{mg} \mathrm{kg}^{-1}\right)$} & \\
\cline { 2 - 4 } & Chestnut oak & Red maple & Pin oak \\
\hline Control & $289.8(23.8) \mathrm{ab}$ & $344.2(13.1) \mathrm{ab}$ & $489.6(23.4) \mathrm{a}$ \\
Peat moss & $252.5(19.9) \mathrm{b}$ & $250.9(37.2) \mathrm{b}$ & $269.4(21.2) \mathrm{b}$ \\
Leaf-based compost & $371.9(38.7) \mathrm{a}$ & $389.5(18.0) \mathrm{a}$ & $501.3(47.9) \mathrm{a}$ \\
Biosolids-based compost & $370.0(30.8) \mathrm{a}$ & $382.1(35.7) \mathrm{a}$ & $463.3(68.5) \mathrm{a}$ \\
Pooled value & $319.5(16.6) \mathrm{B}$ & $341.6(16.1) \mathrm{B}$ & $427.2(11.6) \mathrm{B}$ \\
\hline
\end{tabular}

and root activity were both responding to amendment type. The complex relations among roots, root exudates, microbial activity, microbial exudates, and soil structure could be expected to be reflected in soil respiration. Indeed, PM-treated trees generally had lower soil respiration levels during the growing season, although only occasionally could these differences be reliably attributed to treatment (Figure 6). Carbon/nitrogen ratio remained stable during the course of measurements for all soil treatments except PM (Figure 4). MBC may have in part been suppressed in PM because of low nitrogen content. Fungi and bacteria are reported to be nitrogen limited at substrate $\mathrm{C} / \mathrm{N}$ ratios above 30 (Kaye and Hart 1997). However, the relationship between $\mathrm{C} / \mathrm{N}$ ratio and plant-microbial competition for nitrogen has been questioned. Månsson et al. (2009) found such competition to be uncoupled from $\mathrm{C} / \mathrm{N}$ ratios of 20,31 , and 34 - similar to the ranges of $\mathrm{C} / \mathrm{N}$ for $\mathrm{PM}$ during the current measurement period. In this study, regression analysis suggested that both $\mathrm{C} / \mathrm{N}$ ratio and nitrogen were drivers of $\mathrm{MBC}$, but only $\mathrm{PM}$ had $\mathrm{C} / \mathrm{N}$ ratios of 15 or greater, so it is not possible to determine if higher $\mathrm{C} / \mathrm{N}$ ratios suppressed $\mathrm{MBC}$, or another attribute of $\mathrm{PM}$. Below $14, \mathrm{C} / \mathrm{N}$ ratio was not limiting to microbial biomass.

\section{Were changes mediated in part by increased root prolifera- tion in the enhanced backfill soil, which in turn sustained organic matter deposition to the root zone?}

Tree roots play a direct role in soil aggregate formation through mechanical alteration of the soil and an indirect role through root exudates and turnover, which create opportunities for the nucleation of mineral particles around these plant residues to form aggregates (Kay 1998). In addition, long-term studies with birch trees (Betula spp.) indicate that tree species can have a pronounced cascading effect on soil ecology, especially the microbial community (Mitchell et al. 2007; Mitchell et al. 2010). In this study, chestnut oak had lower root zone microbial biomass carbon accumulation than pin oak overall (see Table 3). Chestnut oak also had distinctively less root length than either red maple or pin oak (Figure 1). Root length is important because this produces a greater soil/root contact surface. Soil in the traditional rhizosphere (soil in immediate contact with the root surface) has greater microbial activity than other soil (Wardle 1992). This effect can vary among both tree species and soil types (Priha et al. 1999; Priha et al. 2001). In the current study, pin oak and red maple root zones had greater root length overall within the core samples than chestnut oak. It should be noted that the root sampling procedure for this study was not intended to characterize overall tree growth or performance and the extent of root growth or total root growth. Instead, the study aimed to assess the relations between root length and soil biological response. Thus, pin oak also had greater MBC when compared to chestnut oak root zones, indicating a possible association between root growth and $\mathrm{MBC}$ in the oak species. Within each species, MBC responded similarly to the various organic amendments (i.e., there was no interaction), yet there was also a pronounced species effect on MBC that may be related to degree of root proliferation. It is possible that other species characteristics may have resulted in greater MBC in pin oak. In addition, although red maple had greater root length than chestnut oak, differences in MBC could not be attributed to species. Nonetheless, when MBC was regressed with cumulative fine root length, there was a significant relationship and fine root length explained $19 \%$ of the variation in $\mathrm{MBC}$, suggesting that MBC was influenced to some degree by fine root proliferation (Figure 5).

The present study only included amendment of a small region of soil immediately surrounding the planted tree. Larger areas of soil amendment might be expected to have greater effect on tree growth overall, and thus a concomitant increase in the role of roots in the ecology of the soil. Incorporating organic matter into backfill soil in urbanized or degraded sites is thought to create a more favorable rooting environment for transplanted trees by reducing soil strength, improving water retention, and enhancing nutrient content (Ferrini et al. 2005; Roberts 2006; Cogger et al. 2008; Price et al. 2009). This practice is widely believed to improve tree survival and growth, which are key determinants of successful tree plantings. The researchers amended individual planting holes to assure root exploration in the study zone during the time of the experiment. However, in practice, the proportion of the soil area explored for the expanding root system would rapidly increase since roots of similar sized transplants can grow approximately $1 \mathrm{~m}$ per year in this climate (Richardson-Calfee et al. 2004).

Nonetheless, although organic amendment incorporation had no effect on root length of chestnut oak or pin oak, red maple root length was clearly increased by leaf-based compost (Figure 1). Other researchers have found red maple root development to be responsive to organic amendment (Smalley and Wood 1995; Kelting et al. 1998; Roberts 2006). While differential species responses to amendments are not surprising when comparing experiments that assumedly differ in a multitude of influential factors, the current experiment has shown that some tree species may respond differently even under identical environmental conditions. Greater root response by red maple may reflect the species' high physiological plasticity (Kelly et al. 2000; Bauerle et al. 2003), which permits red maples to thrive in a broader range of habitats than either pin oak or chestnut oak. In addition, composts contain plant nutrients, such as $\mathrm{P}$ and $\mathrm{N}$, which have the potential to improve plant growth. Conversely, amendment-induced root growth may seem counterintuitive given that increased soil resource levels generally result in decreased root growth (as demonstrated for 
red maple by Canham et al. 1996) as plants efficiently reallocate carbon to other sinks. However, amendment effects on soil nutrient content may be confounded by effects on soil physical properties, which may exert great control on root responsiveness, particularly in a compacted or poorly structured native soil. Of primary interest here, however, is whether organic matter used as soil amendments can create a more sustainable root zone by enhancing the intimate relations between roots, microbial communities, and soil mineral particles that have the potential to result in enhanced soil aggregation and sustained carbon stores (Kay 1998).

Tree root growth responses to organic soil amendments are varied and may reflect changes to soil physical, chemical, or biological characteristics. Past work has demonstrated amendments can increase tree root growth (Smalley and Wood 1995; Prince et al. 2000), as was found in red maple, or have no effect (Kelting et al. 1998; Gilman 2004), as was found with both oak species. This study was conducted in an agricultural soil of adequate quality for producing nursery trees. In degraded urban soils where the microbial community may be more impoverished (Scharenbroch et al. 2005) and soil physical properties may inhibit root growth (Daddow and Warrington 1983; Day et al. 2000), rooting may be restricted and increases in microbial activity connected with amendments could be less pronounced.

\section{CONCLUSION}

This study demonstrated that incorporating organic amendments into the backfill soil of transplanted deciduous trees can affect soil microbial biomass carbon and soil carbon levels as long as 33 months after a single application. Changes in the root-zone soil were both species- and amendment-specific. Red maple, a physiologically plastic tree species, showed greater root length response to organic amendments than the more specialized species, pin oak and chestnut oak. In addition, peat moss amendment suppressed microbial biomass and respiration compared to leaf-based and biosolids-based compost. The very high initial $\mathrm{C} / \mathrm{N}$ ratio of the peat moss amendment remained higher than other treatments during the measurement period. Greater fine and total root length in red maple corresponded with increases in microbial biomass, suggesting that microbial activity was mediated to some extent by root activity. These changes in root zone ecology could have long-term consequences for tree performance or soil health - aspects that deserve attention in future research, although this study did not address overall tree growth or performance or root exploration outside of the backfilled area. In the face of global climate change and rapid urbanization, society must find sustainable uses for urban organic resources. Because soils in disturbed urban environments often lack suitable properties for sustainable tree development, amending impoverished soils with composts may hold promise for restoring soil function and enhancing urban canopy development.

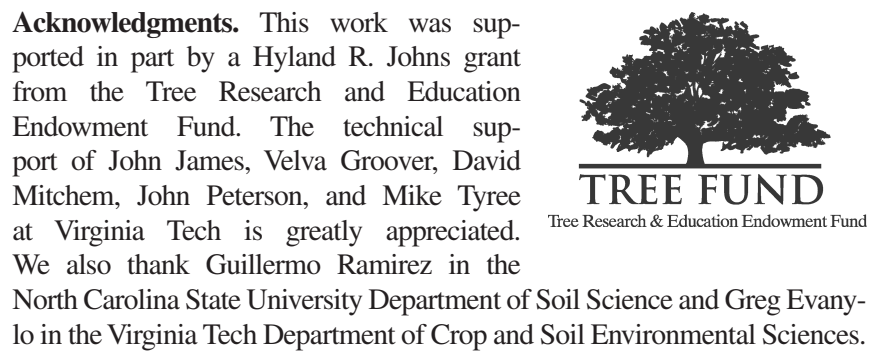

\section{LITERATURE CITED}

Annabi, M., S. Houot, C. Francou, M. Poitrenaud, and Y. Le Bissonnais. 2007. Soil aggregate stability improvement with urban composts of different maturities. Soil Science Society of America Journal 71:413-423.

Bauerle, W.L., J.B. Dudley, and L.W. Grimes. 2003. Genotypic variability in photosynthesis, water use, and light absorption among red and Freeman maple cultivars in response to drought stress. Journal of the American Society for Horticultural Science 128:337-342.

Bowden, C., J. Spargo, and G. Evanylo. 2007. Mineralization and N fertilizer equivalent value of composts as assessed by tall fescue (Festuca arundinacea). Compost Science \& Utilization 15:111-118.

Brant, J.B., D.D. Myrold, and E.W. Sulzman. 2006. Root controls on soil microbial community structure in forest soils. Oecologia 148:650-659.

Canham, C.D., A.R. Berkowitz, V.R. Kelly, G.M. Lovett, S.V. Ollinger, and J. Schnurr. 1996. Biomass allocation and multiple resource limitation in tree seedlings. Canadian Journal of Forest Research-Revue Canadienne De Recherche Forestiere 26:1521-1530.

Chapman, S., A. Buttler, A.-J. Francez, F. Laggoun-Defarge, H. Vasander, M. Schloter, J. Combe, P. Grosvernier, H. Harms, D. Epron, D. Gilbert, and E. Mitchell. 2003. Exploitation of northern peatlands and biodiversity maintenance: a conflict between economy and ecology. Frontiers in Ecology and the Environment 1:525-532.

Chen, W., A.J. Hoitink, and L.V. Madden. 1988. Microbial activity and biomass in container media for predicting suppressiveness to damping-off caused by Pythium ultinum. Phytopathology 78:1447-1450.

Chen, Y., H. Magen, J. Riov. 1994, Humic substances originating from rapidly decomposing organic matter - properties and effects on plant growth. In: N. Senesi and T.M. Miano (Eds.). Humic Substances in the Global Environment and Implications on Human Health. Elsevier Science Publ B V, Amsterdam, pp. 427-443.

Cheng, Z., and P.S. Grewal. 2009. Dynamics of the soil nematode food web and nutrient pools under tall fescue lawns established on soil matrices resulting from common urban development activities. Applied Soil Ecology 42:107-117.

Cogger, C., R. Hummel, J. Hart, and A. Bary. 2008. Soil and red osier dogwood response to incorporated and surface-applied compost. Hortscience 43:2143-2150.

Cogger, C.G. 2005. Potential compost benefits for restoration of soils disturbed by urban development. Compost Science \& Utilization 13:243-251.

Daddow, R.L., and G.E. Warrington. 1983, Growth-limiting soil bulk densities as influenced by soil texture, USDA Forest Service, Fort Collins, 21

Day, S.D., J.R. Seiler, and N. Persaud. 2000. A comparison of root growth dynamics of silver maple and flowering dogwood in compacted soil at differing soil water contents. Tree Physiology 20:257-263.

Day, S.D., N.L. Bassuk, and H. van Es. 1995. Effects of four compaction remediation methods for landscape trees and soil aeration, mechanical impedance and tree establishment. Journal of Environmental Horticulture 13:64-71.

Doran, J.W. 2002. Soil health and global sustainability: Translating science into practice. Agriculture Ecosystems \& Environment 88:119-127.

Ekblad, A., and A. Nordgren. 2002. Is growth of soil microorganisms in boreal forests limited by carbon or nitrogen availability? Plant and Soil 242:115-122.

Ferrini, F., A. Giuntoli, F.P. Nicese, S. Pellegrini, and N. Vignozzi. 2005. Effect of fertilization and backfill amendments on soil characteristics, growth, and leaf gas exchange of English oak (Quercus robur L.). Journal of Arboriculture 31:182-190. 
Fogel, R., and G. Hunt. 1983. Contribution of mycorrhizae and soil fungi to nutrient cycling in a Douglas-fir ecosystem. Canadian Journal of Forest Research 13:219-232.

Forge, T.A., E.J. Hogue, G. Neilsen, and D. Neilsen. 2008. Organic mulches alter nematode communities, root growth and fluxes of phosphorus in the root zone of apple. Applied Soil Ecology 39:15-22.

Gilman, E.F. 2004. Effects of amendments, soil additives, and irrigation on tree survival and growth. Journal of Arboriculture 30:301-310.

Grandy, A S., M.S. Strickland, C.L. Lauber, M.A. Bradford, N. Fierer. 2009. The influence of microbial communities, management, and soil texture on soil organic matter chemistry. Geoderma 150:278-286.

Grayston, S.J., D. Vaughan, and D. Jones. 1997. Rhizosphere carbon flow in trees in comparison with annual plants: The importance of root exudation and its impact on microbial activity and nutrient availability. Applied Soil Ecology 5:29-56.

Hanson, P.J., N.T. Edwards, C.T. Garten, and J.A. Andrews. 2000. Separating root and soil microbial contributions to soil respiration: A review of methods and observations. Biogeochemistry 48:115-146.

Harris, J.R., S.D. Day, and B. Kane. 2008. Nitrogen fertilization during planting and establishment of the urban forest: A collection of five studies. Urban Forestry \& Urban Greening 7:195-206.

Hoitink, H.A.J., A.G. Stone, and D.Y. Han. 1997. Suppression of plant diseases by composts. Hortscience 32:184-187.

Horwath, W.R., and E.A. Paul. 1994, Microbial biomass. In: R.W. Weaver (Ed.). Methods of Soil Analysis, Part 2. Soil Science Society of America, Madison, Wisconsin, U.S. pp. 753-773.

Jim, C.Y. 1998. Urban soil characteristics and limitations for landscape planting in Hong Kong. Landscape and Urban Planning 40:235-249.

Kay, B.D. 1998. Soil structure and organic carbon: A review. In: R. Lal, J.M. Kimble, R.F. Follett, and B.A. Stewart (Eds.). Soil Processes and the Carbon Cycle. CRC Press, Boca Raton, Florida, U.S. pp. 169-197.

Kaye, J.P., and S.C. Hart. 1997. Competition for nitrogen between plants and soil microorganisms. Trends in Ecology \& Evolution 12:139-143.

Kelly, J.M., W.R. Graves, and A. Aiello. 2000. Nitrate uptake kinetics for rooted cuttings of Acer rubrum L. Plant and Soil 221:221-230.

Kelting, M., J.R. Harris, J. Fanelli, and B. Appleton. 1998. Biostimulants and soil amendments affect two-year posttransplant growth of red maple and Washington hawthorn. Hortscience 33:819-822.

Lee, K.E., and C.E. Pankhurst. 1992. Soil organisms and sustainable productivity. Australian Journal of Soil Research 30:855-892.

Lynch, J.M., and E. Bragg. 1985. Microorganisms and soil aggregate stability. Advances in Soil Science, USA 2:133-171.

Lynch, J.M., and J.M. Whipps. 1990. Substrate flow in the rhizosphere. Plant and Soil 129:1-10.

Månsson, K., P. Bengtson, U. Falkengren-Grerup, and G. Bengtsson. 2009. Plant-microbial competition for nitrogen uncoupled from soil C:N ratios. Oikos 118:1908-1916.

McDonald, A.G., W.J. Bealey, D. Fowler, U. Dragosits, U. Skiba, R.I. Smith, R.G. Donovan, H.E. Brett, C.N. Hewitt, and E. Nemitz. 2007. Quantifying the effect of urban tree planting on concentrations and depositions of PM10 in two UK conurbations. Atmospheric Environment 41:8455-8467.

McPherson, G., J.R. Simpson, P.J. Peper, S.E. Maco, and Q.F. Xiao. 2005. Municipal forest benefits and costs in five U.S. cities. Journal of Forestry 103:411-416.

Meharg, A.A., and K. Killham. 1991. A novel method of quantifying root exudation in the presence of soil microflora. Plant and Soil 133:111-116.

Mitchell, R.J., C.D. Campbell, S.J. Chapman, and C.M. Cameron. 2010. The ecological engineering impact of a single tree species on the soil microbial community. Journal of Ecology 98:50-61.
Mitchell, R.J., C.D. Campbell, S.J. Chapman, G.H.R. Osler, A.J. Vanbergen, L.C. Ross, C.M. Cameron, and L. Cole. 2007. The cascading effects of birch on heather moorland: A test for the top-down control of an ecosystem engineer. Journal of Ecology 95:540-554.

Niklasch, H., and R.G. Joergensen. 2001. Decomposition of peat, biogenic municipal waste compost, and shrub/grass compost added in different rates to a silt loam. Journal of Plant Nutrition and Soil Science 164:365-369.

Nowak, D.J. 2006. Institutionalizing urban forestry as a "biotechnology" to improve environmental quality. Urban Forestry \& Urban Greening 5:93-100.

Nowak, D.J., and D.E. Crane. 2002. Carbon storage and sequestration by urban trees in the USA. Environmental Pollution 116:381-389.

Oliveira, M.G., M. van Noordwijk, S.R. Gaze, G. Brouwer, S. Bona, G. Mosca, K. Hairiah. 2000. Auger sampling, ingrowth cores and pinboard methods. In: A.L. Smit, A.G. Bengough, M. van Noordwijk, A. Pellerin, and S.C. van de Geijn (Eds.). Root Methods: A Handbook. Springer-Verlag, New York, New York, U.S. pp. 175-210.

Pascual, J.A., C. García, T. Hernandez, and M. Ayuso. 1997. Changes in the microbial activity of an arid soil amended with urban organic wastes. Biology and Fertility of Soils 24:429-434.

Pietola, L., and R. Tanni. 2003. Response of seedbed physical properties, soil $\mathrm{N}$ and cereal growth to peat application during transition to conservation tillage. Soil \& Tillage Research 74:65-79.

Pouyat, R.V., I.D. Yesilonis, J. Russell-Anelli, and N.K. Neerchal. 2007. Soil chemical and physical properties that differentiate urban land-use and cover types. Soil Science Society of America Journal 71:1010-1019.

Price, J.G., A.N. Wright, K.M. Tilt, and R.L. Boyd. 2009. Organic matter application improves posttransplant root growth of three native woody shrubs. Hortscience 44:377-383.

Priha, O., S.J. Grayston, R. Hiukka, T. Pennanen, and A. Smolander. 2001. Microbial community structure and characteristics of the organic matter in soils under Pinus sylvestris, Picea abies, and Betula pendula at two forest sites. Biology and Fertility of Soils 33:17-24.

Priha, O., S.J. Grayston, T. Pennanen, and A. Smolander. 1999. Microbial activities related to $\mathrm{C}$ and $\mathrm{N}$ cycling and microbial community structure in the rhizospheres of Pinus sylvestris, Picea abies, and Betula pendula seedlings in an organic and mineral soil. FEMS Microbiology Ecology 30:187-199.

Prince, S.P.M., S. Sivakumar, V. Ravi, and V. Subburam. 2000. The effects of coirpith compost on the growth and quality of leaves of the mulberry plant Morus alba L. Bioresource Technology 72:95-97.

Raviv, M. 1998, Horticultural uses of composted material. In: R.A.K. Szmidt (Ed.). International Symposium on Composting and Use of Composted Materials for Horticulture. International Society Horticultural Science, Leuven 1, pp. 225-234.

Richardson-Calfee, L.E., J.R. Harris, and J.K. Fanelli. 2004. Seasonal effects of transplanting on northern red oak and willow oak. Journal of Environmental Horticulture 22:75-79.

Roberts, B.R. 2006. Compost-containing substrates and their effect on posttransplant growth of containerized tree seedlings. Arboriculture \& Urban Forestry 32:289-296.

Roldan, A., F. García-Orenes, and J. Albaladejo. 1994. Microbial populations in the rhizosphere of Brachypodium retusum and their relationship with stable aggregates in a semiarid soil of southeastern Spain. Arid Soil Research and Rehabilitation 8:105-114

Scharenbroch, B.C., J.E. Lloyd, and J.L. Johnson-Maynard. 2005. Distinguishing urban soils with physical, chemical, and biological properties. Pedobiologia 49:283-296. 
Scheu, S. 2002. The soil food web: Structure and perspectives. European Journal of Soil Biology 38:11-20.

Smalley, T.J., and C.B. Wood. 1995. Effect of backfill amendment on growth of red maple. Journal of Arboriculture 21:247-250.

Sustainable Sites Initiative. 2009. The Sustainable Sites Initiative: Guidelines and Performance Benchmarks 2009.

Tejada, M., M.T. Hernandez, and C. Garcia. 2009. Soil restoration using composted plant residues: effects on soil properties. Soil \& Tillage Research 102:109-117.

U.S. Environmental Protection Agency, 1979. Methods for chemical analysis of water and wastes. EPA/600/4-79/020. National Technology Information Service, Springfield, Virginia, U.S.

van Veen, J.A., E. Liljeroth, L.J.A. Lekkerkerk, and S.C. van de Geijn. 1991. Carbon fluxes in plant-soil systems at elevated atmospheric $\mathrm{CO}_{2}$ levels. Ecological Applications 1:175-181.

Vestberg, M., S. Kukkonen, K. Saari, T. Tuovinen, A. Palojärvi, T. Pitkänen, T. Hurme, M. Vepsäläinen, and M. Niemi. 2009. Effects of cropping history and peat amendments on the quality of a silt soil cropped with strawberries. Applied Soil Ecology 42:37-47.

Voroney, R.P., J.P. Winter, and E.G. Gregorich. 1991, Microbe/plant/soil interactions. In: D.C. Coleman and B. Fry (Eds.). Carbon Isotope Techniques. Academic Press, San Diego, pp. 77-99.

Wardle, D.A. 1992. A comparative assessment of factors which influence microbial biomass carbon and nitrogen levels in soil. Biological Reviews 67:321-358.

Wardle, D.A., 1999. How soil food webs make plants grow. Trends in Ecology \& Evolution 14:418-420.

Widmer, T.L., J.H. Graham, and D.J. Mitchell. 1998. Composted municipal waste reduces infection of citrus seedlings by Phytophthora nicotianae. Plant Disease 82:683-688.

\author{
P. Eric Wiseman \\ Department of Forest Resources \& Environmental Conservation \\ Virginia Tech \\ Blacksburg, Virginia 24061, U.S. \\ pwiseman@vt.edu
}

Susan D. Day (corresponding author)

Department of Forest Resources \& Environmental Conservation and Department of Horticulture

Virginia Tech

310 Cheatham Hall

Blacksburg, Virginia 24061, U.S.

sdd@vt.edu

\section{J. Roger Harris}

Department of Horticulture

Virginia Tech

Blacksburg, Virginia 24061, U.S.

rharris@vt.edu
Résumé. Il y a un intérêt accru envers l'amendement des sols dégradés avec de la matière organique afin d'améliorer la qualité du sol, surtout en milieux urbains où la réhabilitation des sols perturbés peut permettre d'améliorer la croissance des arbres et l'apport en bienfaits au niveau de l'écosystème. Afin d'évaluer le potentiel de ces amendements organiques pour produire une modification soutenue au niveau des caractéristiques biologiques du sol, les chercheurs ont étudié les effets de trois amendements organiques incorporés dans la zone racinaire de trois espèces d'arbres, et ce par rapport au développement racinaire, à la dynamique du carbone dans le sol et à la biomasse microbienne durant une période complète d'une année qui a débuté 20 mois après l'application de l'amendement. L'amendement du sol avec un compost de bio-solides mélangés à base de feuilles appliqué sur une plus petite superficie a permis d'accroître le développement des racines à l'intérieur de la zone amendée chez l'érable rouge (Acer rubrum), mais pas chez le chêne des marais (Quercus palustris) ou le chêne châtaignier (Quercus montana). Il y avait un accroissement concomitant de la biomasse microbienne en carbone chez l'érable rouge. Toutes les espèces confondues, l'amendement en tourbe de sphaigne diminuait la biomasse microbienne en carbone de $47 \%$ comparativement aux arbres dont la zone racinaire avait été non amendée et il y avait une suppression maximale de la respiration saisonnière du sol. Par comparaison, le compost à base de feuilles accroissait la biomasse microbienne en carbone de $12 \%(\mathrm{P}=0.0989)$ par rapport aux zones racinaires non amendées. Les ratios carbone/azote demeuraient stables pratiquement toute l'année à l'exception de ceux mesurés dans les zones racinaires chez le chêne châtaignier et le chêne des marais amendées avec de la tourbe où il y avait alors un déclin de 44 à $85 \%$. La quantité totale de carbone du sol demeurait stable avec tous les traitements, même si les sols non amendés avaient une moyenne qui était de $40 \%$ inférieure par rapport à ceux amendés. Toutes espèces confondues, l'accroissement cumulatif en longueur des racines permettait d'expliquer $19 \%$ de la variation en biomasse microbienne en carbone. Les auteurs de cette étude concluent que l'activité microbienne du sol peut être accrue par un amendement en compost dans la zone racinaire et que cet accroissement est réalisé jusqu'à un certain degré par les racines des arbres. De plus, les ratios stables en carbone/azote suggèrent que cette modification dans la zone des racines peut être maintenue. Des recherches futures pourraient permettre d'éclaircir pourquoi l'amendement en compost combiné avec la plantation d'arbres peut permettre d'accélérer la restauration des sols.

Zusammenfassung. Es gibt ein wachsendes Interesse bei der Verbesserung der Qualität degradierter Böden durch organisches Material, besonders in urbanen Flächen, wo die Rehabilitation beschädigter Böden das Wachstum von Bäumen verbessern könnte und zur Verbesserung der Bodenökologie beitragen kann. Zur Untersuchung des Potentials solcher organischen Zuschläge für die Erzielung einer dauerhaften Veränderung bodenbiologischer Charakteristika, haben Forscher die Auswirkungen von drei organischen Zuschlägen auf die Wurzelentwicklung, die Dynamik des Bodenkohlenstoffs und die mikrobielle Bodenbiomasse untersucht, die innerhalb eines Jahres beginnend mit 20 Monaten nach der Applikation in den Wurzelbereich von drei Baumarten eingearbeitet wurden. Eine Bodenverbesserung mit blatthaltigen und zu einem geringeren Anteil auf Feststoffanteilen beruhenden Komposten verursachte ein Wurzelwachstum innerhalb der angereicherten Zone bei Rotahorn (Acer rubrum), aber nicht bei Sumpfeiche (Quercus palustris) oder Bergeiche $(Q$. montana). Es gab einen begleitenden Anstieg beim mikrobiellen Bodenkohlenstoffanteil bei Rotahorn. Bei allen Arten 
reduzierte der Zuschlag von Torf den mikrobiellen Bodenkohlenstoffanteil um $47 \%$ verglichen mit unbehandelten Wurzelbereichen und reduzierte die maximale saisonale Bodenatmung in Relation zu Komposten. Im Gegensatz dazu verbessern blattbasierende Komposte den mikrobiellen Bodenkohlenstoffanteil um $12 \%(\mathrm{P}=0,0989)$, verglichen mit unbehandelten Wurzelzonen. Das Kohlenstoff/Stickstoffverhältnis blieb die meiste Zeit über das Jahr stabil, außer in den Wurzelbereichen von Bergeiche und Sumpfeiche, die mit Torf angereichert wurden, wo das Verhältnis um 44-85\% sank. Der totale Bodenkohlenstoffanteil blieb in allen Behandlungen stabil, obwohl unangereichterte Böden um ca. 40 \% niedriger lagen als die angereicherten Böden. Bei allen Arten und Behandlungen verdeutlichte die kumulative Feinwurzellänge 19\% der Abweichungen in mikrobieller Bodenkohlenstoffmasse. Die Autoren dieser Studie schließen daraus, dass die mikrobielle Bodenaktivität durch den Zuschlag von komposthaltigen Zuschlagstoffen in der Wurzelzone gesteigert werden kann und dass dieser Anstieg zu einem gewissen Grad durch Baumwurzeln erzielt wird. Zusätzlich deuten stabile $\mathrm{C} / \mathrm{N}-$ Verhältnisse an, dass die Veränderung in der Wurzelzone dauerhaft ist. Weitere Forschung könnte klären, ob Kompostzuschläge in Kombination mit der Baumpflanzung die Bodenverbesserung bescheunigen kann.

Resumen. Existe un creciente interés en tratar los suelos degradados con materia orgánica para mejorar la calidad del suelo, especialmente en áreas urbanas donde la rehabilitación de suelos dañados puede mejorar el crecimiento de los árboles y proveer servicios al ecosistema. Para evaluar el potencial de tales mejoradores orgánicos, para producir una modificación sostenida en las características biológicas de los suelos, los investigadores estudiaron los efectos de tres mejoradores orgánicos incorporados a la zona de raíces de tres especies en el desarrollo de la raíz, las dinámicas del carbono en el suelo, y biomasa microbiana en el suelo en un año empezando 20 meses después de su aplicación. El mejoramiento del suelo con composta a base de hojas, y a menor extensión, los compuestos con base en biosólidos, incrementaron la longitud de la raíz dentro de la zona radicular mejorada de maple rojo (Acer rubrum), pero no en encino rosado (Quercus palustris) o encino castaño (Q. montana). Hubo un incremento concomitante en la biomasa microbiana de carbón por $47 \%$ comparado a zonas radiculares no enmendadas y respiración del suelo relativa a los compuestos. En contraste, la composta de hojas incrementó la biomasa microbiana de carbón por $12 \%$ ( $\mathrm{P}=0.0989)$ comparado con zonas de raíces no tratadas. La relación carbono/nitrógeno permaneció estable en todos los tratamientos, aunque el promedio de suelos no enmendados bajó $40 \%$ en comparación con los enmendados. En todas las especies y tratamientos, la longitud en promedio de raíces finas explicó 19\% de la variación en biomasa microbiana de carbón. Los autores del estudio concluyen que la actividad microbiana del suelo puede ser incrementada por la composta mejoradora de la zona de raíces y que este incremento es mediado en algún grado por las raíces de los árboles. La futura investigación puede clarificar si los mejoradores combinados con la plantación de los árboles puede acelerar la restauración del suelo. 
Appendix 1. Response variable means and standard errors for each treatment factor level combination $(n=4)$.

\begin{tabular}{|c|c|c|c|c|c|c|c|c|}
\hline \multirow{2}{*}{$\begin{array}{l}\text { Tree species } \\
\text { Soil amendment }\end{array}$} & \multicolumn{8}{|c|}{ Red maple } \\
\hline & \multicolumn{2}{|l|}{$\mathrm{CON}$} & \multicolumn{2}{|l|}{$\mathrm{PM}$} & \multicolumn{2}{|l|}{$\mathrm{BBC}$} & \multicolumn{2}{|l|}{ LBC } \\
\hline $\begin{array}{l}\text { Soil MBC } \\
\left(\mathrm{mg} \mathrm{kg}^{-1}\right)\end{array}$ & 344.2 & 13.1 & 250.88 & 37.15 & 382.08 & 35.74 & 389.46 & 17.98 \\
\hline \multicolumn{9}{|l|}{ Root dry mass (g) } \\
\hline Dec. 2005 & 0.84 & 0.25 & 0.55 & 0.17 & 0.29 & 0.11 & 0.70 & 0.14 \\
\hline Feb. 2006 & 0.70 & 0.27 & 0.43 & 0.14 & 1.22 & 0.25 & 1.50 & 0.52 \\
\hline May 2006 & 0.39 & 0.16 & 0.43 & 0.31 & 1.17 & 0.81 & 1.29 & 0.96 \\
\hline July 2006 & 0.95 & 0.55 & 1.03 & 0.30 & 0.49 & 0.27 & 0.74 & 0.35 \\
\hline Sept. 2006 & 0.48 & 0.09 & 0.78 & 0.33 & 4.07 & 2.13 & 1.21 & 0.71 \\
\hline Nov. 2006 & 0.35 & 0.13 & 0.69 & 0.29 & 0.80 & 0.12 & 0.90 & 0.17 \\
\hline \multicolumn{9}{|c|}{ Fine root length $(\mathrm{cm})$} \\
\hline Dec. 2005 & 314.18 & 133.42 & 276.72 & 55.61 & 385.63 & 142.69 & 461.30 & 75.82 \\
\hline Feb. 2006 & 391.39 & 163.29 & 217.49 & 71.38 & 514.96 & 109.29 & 458.01 & 28.74 \\
\hline May 2006 & 341.52 & 163.69 & 165.33 & 11.79 & 398.27 & 108.74 & 481.69 & 106.95 \\
\hline July 2006 & 372.88 & 177.48 & 253.88 & 51.45 & 567.27 & 54.05 & 624.93 & 105.50 \\
\hline Sept. 2006 & 463.34 & 84.03 & 315.41 & 97.55 & 444.97 & 63.45 & 688.07 & 60.84 \\
\hline Nov. 2006 & 372.71 & 142.52 & 565.52 & 160.53 & 467.72 & 132.41 & 767.93 & 84.87 \\
\hline \multicolumn{9}{|l|}{ Soil C Content (\%) } \\
\hline Dec. 2005 & 1.79 & 0.33 & 1.94 & 0.39 & 3.36 & 0.85 & 2.72 & 0.26 \\
\hline Feb. 2006 & 2.05 & 0.64 & 2.36 & 0.37 & 2.10 & 0.35 & 2.85 & 0.37 \\
\hline May 2006 & 1.81 & 0.39 & 2.29 & 0.31 & 2.09 & 0.37 & 2.35 & 0.22 \\
\hline July 2006 & 1.73 & 0.30 & 3.20 & 0.80 & 2.43 & 0.19 & 2.30 & 0.44 \\
\hline Sept. 2006 & 2.35 & 0.38 & 2.63 & 0.43 & 2.98 & 0.52 & 3.00 & 0.22 \\
\hline Nov. 2006 & 1.99 & 0.40 & 3.32 & 0.99 & 3.27 & 0.57 & 3.77 & 0.26 \\
\hline \multicolumn{9}{|l|}{ Soil N Content (\%) } \\
\hline Dec. 2005 & 0.12 & 0.01 & 0.10 & 0.02 & 0.22 & 0.04 & 0.19 & 0.02 \\
\hline Feb. 2006 & 0.16 & 0.03 & 0.14 & 0.01 & 0.17 & 0.02 & 0.22 & 0.02 \\
\hline May 2006 & 0.15 & 0.02 & 0.13 & 0.01 & 0.18 & 0.02 & 0.19 & 0.01 \\
\hline July 2006 & 0.15 & 0.02 & 0.16 & 0.02 & 0.21 & 0.02 & 0.19 & 0.02 \\
\hline Sept. 2006 & 0.18 & 0.02 & 0.16 & 0.02 & 0.24 & 0.03 & 0.24 & 0.01 \\
\hline Nov. 2006 & 0.17 & 0.02 & 0.18 & 0.03 & 0.25 & 0.03 & 0.28 & 0.01 \\
\hline \multicolumn{9}{|l|}{ Soil C/N Ratio } \\
\hline Dec. 2005 & 14.2 & 0.9 & 20.0 & 1.3 & 14.6 & 0.9 & 14.5 & 0.3 \\
\hline Feb. 2006 & 12.1 & 1.0 & 16.6 & 1.8 & 11.7 & 0.7 & 12.7 & 0.7 \\
\hline May 2006 & 11.8 & 0.8 & 17.3 & 1.8 & 11.4 & 0.5 & 12.3 & 0.3 \\
\hline July 2006 & 11.6 & 0.6 & 19.4 & 2.6 & 11.9 & 0.1 & 12.0 & 0.7 \\
\hline Sept. 2006 & 12.7 & 0.8 & 15.9 & 2.3 & 12.1 & 0.6 & 12.7 & 0.5 \\
\hline Nov. 2006 & 11.6 & 0.6 & 17.4 & 3.3 & 12.7 & 0.7 & 13.6 & 0.6 \\
\hline \multicolumn{9}{|c|}{ Soil Respiration $\left(\mu \mathrm{mol} \mathrm{m} \mathrm{m}^{-2} \mathrm{~s}^{-1}\right)$} \\
\hline Nov. 2005 & 1.36 & 0.15 & 1.28 & 0.29 & 1.70 & 0.48 & 1.44 & 0.23 \\
\hline Dec. 2005 & 0.28 & 0.04 & 0.48 & 0.31 & 0.19 & 0.12 & 0.59 & 0.18 \\
\hline Jan. 2006 & 0.71 & 0.16 & 0.70 & 0.13 & 1.38 & 0.36 & 1.86 & 0.24 \\
\hline Feb. 2006 & 0.34 & 0.12 & 0.22 & 0.03 & 1.01 & 0.75 & 0.34 & 0.08 \\
\hline Mar. 2006 & 0.95 & 0.24 & 1.78 & 0.82 & 1.78 & 0.68 & 1.93 & 0.96 \\
\hline May 2006 & 5.31 & 0.74 & 3.53 & 0.26 & 7.80 & 2.15 & 5.98 & 1.18 \\
\hline June 2006 & 5.29 & 0.80 & 9.46 & 1.31 & 8.56 & 2.08 & 11.00 & 1.73 \\
\hline July 2006 & 12.48 & 2.26 & 11.91 & 3.52 & 24.90 & 1.83 & 26.05 & 4.04 \\
\hline Aug. 2006 & 12.09 & 0.60 & 9.64 & 2.76 & 11.01 & 1.90 & 13.23 & 1.52 \\
\hline Sept. 2006 & 11.94 & 2.34 & 9.25 & 1.78 & 12.56 & 2.49 & 13.65 & 1.62 \\
\hline Oct. 2006 & 7.13 & 1.07 & 7.47 & 1.19 & 7.50 & 1.68 & 15.41 & 1.72 \\
\hline Nov. 2006 & 2.68 & 0.69 & 2.17 & 0.47 & 3.30 & 0.36 & 5.16 & 1.06 \\
\hline
\end{tabular}


Appendix 1 (continued). Response variable means and standard errors for each treatment factor level combination $(n=4)$.

\begin{tabular}{|c|c|c|c|c|c|c|c|c|}
\hline \multirow{2}{*}{$\begin{array}{l}\text { Tree species } \\
\text { Soil amendment }\end{array}$} & \multicolumn{8}{|l|}{ Pin oak } \\
\hline & $\mathrm{CON}$ & & PM & & $\mathrm{BBC}$ & & LBC & \\
\hline $\begin{array}{l}\text { Soil MBC } \\
\left(\mathrm{mg} \mathrm{kg}^{-1}\right)\end{array}$ & 489.56 & 23.42 & 269.41 & 21.25 & 463.27 & 68.48 & 501.26 & 47.87 \\
\hline \multicolumn{9}{|l|}{ Root dry mass (g) } \\
\hline Dec. 2005 & 0.71 & 0.40 & 0.34 & 0.11 & 0.42 & 0.26 & 0.69 & 0.39 \\
\hline Feb. 2006 & 0.26 & 0.04 & 1.52 & 1.17 & 0.16 & 0.02 & 0.42 & 0.07 \\
\hline May 2006 & 0.17 & 0.05 & 0.16 & 0.08 & 0.11 & 0.02 & 0.86 & 0.70 \\
\hline July 2006 & 0.45 & 0.26 & 0.11 & 0.03 & 0.13 & 0.02 & 2.46 & 2.18 \\
\hline Sept. 2006 & 0.55 & 0.22 & 0.16 & 0.05 & 0.11 & 0.05 & 0.85 & 0.64 \\
\hline Nov. 2006 & 0.22 & 0.10 & 0.26 & 0.08 & 1.51 & 1.15 & 2.10 & 1.89 \\
\hline \multicolumn{9}{|c|}{ Fine root length $(\mathrm{cm})$} \\
\hline Dec. 2005 & 366.32 & 160.99 & 537.42 & 131.63 & 387.95 & 51.02 & 443.52 & 42.36 \\
\hline Feb. 2006 & 345.96 & 38.97 & 413.12 & 169.87 & 381.59 & 61.88 & 359.60 & 40.30 \\
\hline May 2006 & 382.57 & 114.27 & 315.56 & 111.13 & 363.87 & 22.23 & 449.32 & 35.58 \\
\hline July 2006 & 330.06 & 25.28 & 309.85 & 132.37 & 360.04 & 35.37 & 373.53 & 83.30 \\
\hline Sept. 2006 & 409.19 & 135.25 & 518.68 & 124.21 & 297.63 & 80.90 & 400.04 & 122.58 \\
\hline Nov. 2006 & 378.07 & 79.35 & 563.39 & 39.93 & 598.84 & 119.99 & 350.40 & 37.81 \\
\hline \multicolumn{9}{|c|}{ Soil C Content (\%) } \\
\hline Dec. 2005 & 1.44 & 0.18 & 3.23 & 0.55 & 2.35 & 0.28 & 2.99 & 0.52 \\
\hline Feb. 2006 & 1.72 & 0.27 & 2.43 & 0.41 & 2.51 & 0.16 & 3.55 & 0.35 \\
\hline May 2006 & 1.59 & 0.15 & 4.18 & 0.41 & 2.66 & 0.26 & 2.88 & 0.24 \\
\hline July 2006 & 1.79 & 0.24 & 3.45 & 1.12 & 2.75 & 0.22 & 2.70 & 0.33 \\
\hline Sept. 2006 & 1.74 & 0.05 & 2.85 & 0.17 & 1.98 & 0.46 & 3.15 & 0.41 \\
\hline Nov. 2006 & 1.90 & 0.23 & 2.06 & 0.38 & 2.67 & 0.13 & 2.26 & 0.34 \\
\hline \multicolumn{9}{|c|}{ Soil N Content (\%) } \\
\hline Dec. 2005 & 0.10 & 0.01 & 0.12 & 0.01 & 0.18 & 0.02 & 0.21 & 0.04 \\
\hline Feb. 2006 & 0.14 & 0.01 & 0.15 & 0.01 & 0.21 & 0.01 & 0.27 & 0.02 \\
\hline May 2006 & 0.14 & 0.01 & 0.17 & 0.01 & 0.21 & 0.02 & 0.22 & 0.02 \\
\hline July 2006 & 0.15 & 0.01 & 0.17 & 0.03 & 0.22 & 0.02 & 0.21 & 0.02 \\
\hline Sept. 2006 & 0.15 & 0.01 & 0.17 & 0.01 & 0.17 & 0.02 & 0.24 & 0.03 \\
\hline Nov. 2006 & 0.16 & 0.01 & 0.14 & 0.01 & 0.22 & 0.01 & 0.19 & 0.02 \\
\hline \multicolumn{9}{|l|}{ Soil C/N Ratio } \\
\hline Dec. 2005 & 14.0 & 0.7 & 25.8 & 3.6 & 13.4 & 0.3 & 14.1 & 0.1 \\
\hline Feb. 2006 & 12.2 & 1.0 & 16.2 & 2.6 & 12.2 & 0.2 & 13.2 & 0.3 \\
\hline May 2006 & 11.3 & 0.6 & 25.3 & 2.3 & 12.5 & 0.3 & 13.1 & 0.2 \\
\hline July 2006 & 11.9 & 0.8 & 18.8 & 2.6 & 12.3 & 0.1 & 12.5 & 0.3 \\
\hline Sept. 2006 & 11.3 & 0.4 & 16.9 & 0.6 & 11.5 & 1.3 & 12.9 & 0.2 \\
\hline Nov. 2006 & 11.7 & 0.8 & 14.0 & 1.6 & 11.9 & 0.2 & 11.7 & 0.8 \\
\hline \multicolumn{9}{|c|}{ Soil Respiration $\left(\mu \mathrm{mol} \mathrm{m} \mathrm{m}^{-2} \mathrm{~s}^{-1}\right)$} \\
\hline Nov. 2005 & 2.18 & 0.44 & 1.72 & 0.18 & 2.72 & 0.30 & 2.95 & 0.51 \\
\hline Dec. 2005 & 0.54 & 0.06 & 2.03 & 1.12 & 0.42 & 0.18 & 1.31 & 0.53 \\
\hline Jan. 2006 & 0.93 & 0.24 & 1.72 & 0.56 & 1.24 & 0.28 & 1.21 & 0.27 \\
\hline Feb. 2006 & 0.84 & 0.10 & 1.35 & 0.42 & 1.03 & 0.22 & 1.08 & 0.12 \\
\hline Mar. 2006 & 2.36 & 0.71 & 0.45 & 0.18 & 1.59 & 0.63 & 3.16 & 1.59 \\
\hline May 2006 & 7.04 & 1.18 & 3.62 & 0.35 & 6.00 & 0.84 & 5.69 & 1.23 \\
\hline June 2006 & 7.86 & 1.34 & 7.63 & 0.94 & 10.18 & 2.11 & 9.01 & 2.10 \\
\hline July 2006 & 13.03 & 2.49 & 7.29 & 1.82 & 11.08 & 3.18 & 8.31 & 1.66 \\
\hline Aug. 2006 & 8.00 & 1.12 & 8.02 & 0.52 & 7.24 & 0.54 & 10.58 & 1.62 \\
\hline Sept. 2006 & 8.95 & 0.52 & 9.75 & 0.93 & 8.91 & 0.29 & 12.89 & 1.27 \\
\hline Oct. 2006 & 9.09 & 1.17 & 6.23 & 1.13 & 8.98 & 1.31 & 9.69 & 2.03 \\
\hline Nov. 2006 & 3.02 & 0.54 & 3.32 & 0.80 & 5.50 & 1.58 & 3.75 & 0.16 \\
\hline
\end{tabular}


Appendix 1 (continued). Response variable means and standard errors for each treatment factor level combination $(n=4)$.

\begin{tabular}{|c|c|c|c|c|c|c|c|c|}
\hline \multirow{2}{*}{$\begin{array}{l}\text { Tree species } \\
\text { Soil amendment }\end{array}$} & \multicolumn{8}{|c|}{ Chestnut oak } \\
\hline & \multicolumn{2}{|l|}{$\mathrm{CON}$} & \multicolumn{2}{|l|}{$\mathrm{PM}$} & \multicolumn{2}{|l|}{$\mathrm{BBC}$} & \multicolumn{2}{|l|}{ LBC } \\
\hline $\begin{array}{l}\text { Soil MBC } \\
\left(\mathrm{mg} \mathrm{kg}^{-1}\right)\end{array}$ & 289.79 & 23.83 & 252.49 & 19.89 & 369.97 & 30.78 & 371.92 & 38.66 \\
\hline \multicolumn{9}{|l|}{ Root dry mass (g) } \\
\hline Dec. 2005 & 0.17 & 0.06 & 0.23 & 0.13 & 0.34 & 0.19 & 0.21 & 0.16 \\
\hline Feb. 2006 & 0.19 & 0.06 & 0.10 & 0.02 & 0.49 & 0.28 & 0.31 & 0.21 \\
\hline May 2006 & 0.15 & 0.04 & 0.74 & 0.39 & 0.63 & 0.59 & 0.19 & 0.07 \\
\hline July 2006 & 0.47 & 0.23 & 0.20 & 0.07 & 0.22 & 0.11 & 2.10 & 1.39 \\
\hline Sept. 2006 & 0.31 & 0.06 & 0.69 & 0.61 & 0.06 & 0.03 & 0.10 & 0.01 \\
\hline Nov. 2006 & 0.47 & 0.14 & 0.13 & 0.06 & 0.31 & 0.23 & 0.12 & 0.03 \\
\hline \multicolumn{9}{|c|}{ Fine root length $(\mathrm{cm})$} \\
\hline Dec. 2005 & 129.43 & 28.87 & 103.92 & 16.08 & 83.92 & 32.89 & 69.24 & 32.82 \\
\hline Feb. 2006 & 140.55 & 69.22 & 99.78 & 25.96 & 181.27 & 34.54 & 97.90 & 19.22 \\
\hline May 2006 & 213.54 & 93.99 & 122.59 & 26.92 & 124.22 & 38.14 & 97.08 & 36.01 \\
\hline July 2006 & 218.52 & 67.95 & 165.86 & 24.87 & 147.18 & 69.15 & 97.89 & 24.18 \\
\hline Sept. 2006 & 238.07 & 48.63 & 150.04 & 50.78 & 110.57 & 43.64 & 172.66 & 43.73 \\
\hline Nov. 2006 & 201.87 & 35.39 & 118.75 & 19.05 & 123.33 & 35.56 & 93.11 & 26.82 \\
\hline \multicolumn{9}{|c|}{ Soil C Content (\%) } \\
\hline Dec. 2005 & 1.18 & 0.05 & 3.88 & 1.40 & 2.67 & 0.32 & 2.69 & 0.46 \\
\hline Feb. 2006 & 1.72 & 0.40 & 4.02 & 0.28 & 2.82 & 0.33 & 3.04 & 0.30 \\
\hline May 2006 & 1.66 & 0.12 & 3.94 & 1.05 & 3.09 & 0.57 & 2.80 & 0.14 \\
\hline July 2006 & 1.54 & 0.11 & 2.45 & 0.39 & 3.10 & 0.40 & 2.52 & 0.49 \\
\hline Sept. 2006 & 2.31 & 0.40 & 2.57 & 0.72 & 3.93 & 0.54 & 3.07 & 0.28 \\
\hline Nov. 2006 & 1.81 & 0.22 & 3.19 & 0.41 & 3.46 & 0.27 & 3.04 & 0.28 \\
\hline \multicolumn{9}{|c|}{ Soil N Content (\%) } \\
\hline Dec. 2005 & 0.09 & 0.01 & 0.14 & 0.02 & 0.19 & 0.02 & 0.18 & 0.03 \\
\hline Feb. 2006 & 0.14 & 0.02 & 0.18 & 0.01 & 0.23 & 0.02 & 0.23 & 0.02 \\
\hline May 2006 & 0.14 & 0.01 & 0.18 & 0.02 & 0.25 & 0.03 & 0.21 & 0.01 \\
\hline July 2006 & 0.13 & 0.01 & 0.15 & 0.01 & 0.25 & 0.03 & 0.20 & 0.03 \\
\hline Sept. 2006 & 0.18 & 0.02 & 0.14 & 0.02 & 0.29 & 0.03 & 0.24 & 0.02 \\
\hline Nov. 2006 & 0.16 & 0.01 & 0.17 & 0.02 & 0.30 & 0.02 & 0.23 & 0.02 \\
\hline \multicolumn{9}{|l|}{ Soil C/N Ratio } \\
\hline Dec. 2005 & 13.5 & 0.3 & 25.8 & 4.2 & 13.9 & 0.3 & 14.9 & 0.2 \\
\hline Feb. 2006 & 12.0 & 0.9 & 22.2 & 1.5 & 12.3 & 0.4 & 13.0 & 0.1 \\
\hline May 2006 & 11.8 & 0.5 & 20.9 & 3.0 & 12.3 & 0.6 & 13.5 & 0.4 \\
\hline July 2006 & 11.4 & 0.3 & 16.2 & 1.7 & 12.5 & 0.3 & 12.6 & 0.5 \\
\hline Sept. 2006 & 12.9 & 0.8 & 16.9 & 3.0 & 13.3 & 0.6 & 12.9 & 0.2 \\
\hline Nov. 2006 & 11.3 & 0.6 & 18.1 & 0.9 & 11.8 & 1.1 & 12.9 & 0.4 \\
\hline \multicolumn{9}{|c|}{ Soil Respiration $\left(\mu \mathrm{mol} \mathrm{m} \mathrm{m}^{-2} \mathrm{~s}^{-1}\right)$} \\
\hline Nov. 2005 & 1.03 & 0.14 & 1.61 & 0.43 & 2.18 & 0.75 & 1.03 & 0.26 \\
\hline Dec. 2005 & 0.78 & 0.15 & 0.90 & 0.32 & 0.96 & 0.59 & 0.58 & 0.14 \\
\hline Jan. 2006 & 0.92 & 0.12 & 1.31 & 0.53 & 1.18 & 0.40 & 1.05 & 0.27 \\
\hline Feb. 2006 & 0.44 & 0.15 & 0.89 & 0.19 & 0.64 & 0.20 & 0.42 & 0.17 \\
\hline Mar. 2006 & 1.71 & 0.44 & 1.87 & 0.21 & 1.60 & 0.20 & 1.69 & 0.58 \\
\hline May 2006 & 5.47 & 0.96 & 5.45 & 1.04 & 7.03 & 1.39 & 5.30 & 0.97 \\
\hline June 2006 & 7.31 & 2.80 & 10.26 & 1.87 & 10.71 & 3.02 & 9.15 & 2.23 \\
\hline July 2006 & 16.48 & 6.11 & 14.29 & 3.21 & 24.18 & 5.14 & 20.19 & 3.45 \\
\hline Aug. 2006 & 14.20 & 5.79 & 8.73 & 1.40 & 15.60 & 3.70 & 12.09 & 2.70 \\
\hline Sept. 2006 & 6.92 & 2.03 & 5.51 & 0.78 & 8.40 & 1.09 & 6.42 & 1.26 \\
\hline Oct. 2006 & 7.33 & 1.72 & 8.99 & 1.61 & 7.82 & 0.50 & 6.55 & 1.25 \\
\hline Nov. 2006 & 1.88 & 0.67 & 1.15 & 0.24 & 2.40 & 0.71 & 1.83 & 0.24 \\
\hline
\end{tabular}

